Article

\title{
Preparation of "Constrained Geometry" Titanium Complexes of [1,2]Azasilinane Framework for Ethylene/1-Octene Copolymerization
}

\author{
Seul Lee, Seung Soo Park, Jin Gu Kim, Chung Sol Kim and Bun Yeoul Lee * \\ Department of Molecular Science and Technology, Ajou University, Suwon 443-749, Korea; \\ dew6745@ajou.ac.kr (S.L.); zerg113@ajou.ac.kr (S.S.P.); juniori@ajou.ac.kr (J.G.K.); fubu50f@ajou.ac.kr (C.S.K.) \\ * Correspondence: bunyeoul@ajou.ac.kr; Tel.: +82-031-219-1844
}

Academic Editor: Kotohiro Nomura

Received: 27 December 2016; Accepted: 7 February 2017; Published: 9 February 2017

\begin{abstract}
The $\mathrm{Me}_{2} \mathrm{Si}$-bridged ansa-Cp/amido half-metallocene, $\left[\mathrm{Me}_{2} \mathrm{Si}\left(\eta^{5}-\mathrm{Me}_{4} \mathrm{C}_{5}\right)\left(\mathrm{N}^{t} \mathrm{Bu}\right)\right] \mathrm{TiCl}_{2}$, termed a "constrained-geometry catalyst (CGC)", is a representative homogeneous Ziegler catalyst. CGC derivatives with the [1,2]azasilinane framework, in which the amide alkyl substituent is joined by the Si-bridge, were prepared, and the catalytic performances of these species was studied. $\mathrm{Me}_{4} \mathrm{C}_{5} \mathrm{HSi}(\mathrm{Me})\left(\mathrm{CH}_{2} \mathrm{CH}=\mathrm{CH}_{2}\right)-\mathrm{NH}\left(\mathrm{C}(\mathrm{R})\left(\mathrm{R}^{\prime}\right) \mathrm{CH}=\mathrm{CH}_{2}\right)\left(\mathrm{R}, \mathrm{R}^{\prime}=\mathrm{H}\right.$ or methyl; $\mathrm{Me}_{4} \mathrm{C}_{5} \mathrm{H}=$ tetramethylcyclopentadienyl) was susceptible to ring closure metathesis (RCM) when treated with Schrock's Mo-catalyst to afford $-\mathrm{Si}\left(\mathrm{Me}_{4} \mathrm{C}_{5} \mathrm{H}\right)(\mathrm{Me}) \mathrm{CH}_{2} \mathrm{CH}=\mathrm{CHC}(\mathrm{R})\left(\mathrm{R}^{\prime}\right) \mathrm{NH}$ - containing a six-membered ring framework. Using the precursors and the products of $\mathrm{RCM}$, various $\mathrm{CGC}$ derivatives, i.e., $\left[-\mathrm{Si}\left(\eta^{5}-\mathrm{Me}_{4} \mathrm{C}_{5}\right)(\mathrm{Me}) \mathrm{CH}_{2} \mathrm{CH}=\mathrm{CHC}(\mathrm{R})(\mathrm{H}) \mathrm{N}-\mathrm{TiMe}_{2}(13, \mathrm{R}=\mathrm{H} ; 15, \mathrm{R}=\mathrm{Me}),\left[-\mathrm{Si}\left(\eta^{5}-\mathrm{Me}_{4} \mathrm{C}_{5}\right)(\mathrm{Me})\right.\right.$ $\mathrm{CH}_{2} \mathrm{CH}_{2} \mathrm{CH}_{2} \mathrm{CH}_{2} \mathrm{~N}_{\mathrm{TiMe}}$ (14), $\quad\left[\left(\eta^{5}-\mathrm{Me}_{4} \mathrm{C}_{5}\right) \mathrm{Si}(\mathrm{Me})\left(\mathrm{CH}_{2} \mathrm{CH}=\mathrm{CH}_{2}\right) \mathrm{NCH}_{2} \mathrm{CH}=\mathrm{CH}_{2}\right] \mathrm{TiMe}_{2}$ (16), $\left[\left(\eta^{5}-\mathrm{Me}_{4} \mathrm{C}_{5}\right) \mathrm{Si}(\mathrm{Me})\left(\mathrm{CH}=\mathrm{CH}_{2}\right) \mathrm{NCH}_{2} \mathrm{CH}=\mathrm{CH}_{2}\right] \mathrm{TiMe}_{2}(\mathbf{1 7})$, and $\left[\left(\eta^{5}-\mathrm{Me}_{4} \mathrm{C}_{5}\right) \mathrm{Si}(\mathrm{Me})\left(\mathrm{CH}_{2} \mathrm{CH}_{3}\right) \mathrm{NCH}_{2}\right.$ $\left.\mathrm{CH}_{2} \mathrm{CH}_{3}\right] \mathrm{TiMe}_{2}$ (18), were prepared. The catalytic activity of the newly prepared complexes was lower than that of CGC when activated with $\left[\mathrm{Ph}_{3} \mathrm{C}\right]\left[\mathrm{B}\left(\mathrm{C}_{6} \mathrm{~F}_{5}\right)_{4}\right] / \mathrm{iBu}_{3} \mathrm{Al}$. However, the catalytic activity of these species was improved by using tetrabutylaluminoxane $\left(\left[\mathrm{iBu}_{2} \mathrm{Al}_{2} \mathrm{O}\right)\right.$ instead of $\mathrm{iBu}_{3} \mathrm{Al}$ and the activity of $14 /\left[\mathrm{Ph}_{3} \mathrm{C}\right]\left[\mathrm{B}\left(\mathrm{C}_{6} \mathrm{~F}_{5}\right)_{4}\right] /\left[\mathrm{iBu}_{2} \mathrm{Al}_{2} \mathrm{O}\right.$ was comparable to that of $\mathrm{CGC} /\left[\mathrm{Ph}_{3} \mathrm{C}\right]\left[\mathrm{B}\left(\mathrm{C}_{6} \mathrm{~F}_{5}\right)_{4}\right] / \mathrm{iBu}_{3} \mathrm{Al}$ (4.7 and $5.0 \times 10^{6} \mathrm{~g} / \mathrm{mol}-\mathrm{Ti}$, respectively). Advantageously, the newly prepared complexes produced higher molecular weight poly(ethylene-co-1-octene)s than CGC.
\end{abstract}

Keywords: olefin polymerization; titanium complex; constrained geometry; half-metallocene

\section{Introduction}

Since the discovery of homogeneous metallocene catalysts (single-site polyolefin catalysts) in the 1970s by Kaminsky, their industrial impact has escalated, with current annual production of more than five million tons of polyolefins [1-3]. The initially developed family of metallocene-type catalytic species has expanded to include half-metallocenes constructed with a cyclopentadienyl (Cp) and an amido ligand [4-10], and further to post-metallocenes (or non-metallocenes) comprising non-cyclopentadienyl ligands [11-16]. Among the homogeneous Ziegler catalysts, $\mathrm{Me}_{2} \mathrm{Si}$-bridged ansa-Cp/amido half-metallocenes, a typical example of which is $\left[\mathrm{Me}_{2} \mathrm{Si}\left(\eta^{5}-\mathrm{Me}_{4} \mathrm{C}_{5}\right)\left(\mathrm{N}^{t} \mathrm{Bu}\right)\right] \mathrm{TiCl}_{2}$, are termed "constrained-geometry catalysts (CGCs, Chart 1)", and have drawn significant attention from both industry and academia. CGC exhibits excellent catalytic performance, including high activity, high $\alpha$-olefin incorporation, and high thermal stability [17-22]. We also reported a variety of ansa-Cp/amido half-metallocene congeners bearing the ortho-phenylene-bridge instead of the $\mathrm{Me}_{2} \mathrm{Si}$-bridge (1 in Chart 1) [23,24]. During the course of development of these catalysts, we observed that the tetrahydroquinoline (or tetrahydroquinaldine) derived species ( 2 in Chart 1$)$, in which 
the alkyl substituent in the amido ligand is joined to the ortho-phenylene-bridge, exhibited higher activity and higher $\alpha$-olefin incorporation than the simple ortho-phenylene-bridged ansa-Cp/amido congeners 1 [25-28]. In fact, 2 displays excellent catalytic performance in ethylene/ $\alpha$-olefin copolymerization, thus enabling its use in commercial processes $[29,30]$. Joining the amide alkyl substituent and ortho-phenylene-bridge may afford a highly accessible reaction site for catalysis, resulting in higher activity and higher $\alpha$-olefin incorporation. This observation prompted us to prepare CGC analogues in which the amide alkyl substituent is joined to the Si-bridge unit to form the [1,2]azasilinane framework (Chart 1). Various CGC derivatives have been reported; in most of these cases, the $\mathrm{Me}_{4} \mathrm{C}_{5}$-unit is replaced with other $\pi$-donor ligands or the $\mathrm{N}^{t} \mathrm{Bu}$-unit is replaced with other amides or phosphides. However, the complexes targeted in this work have not previously been prepared [31-39].

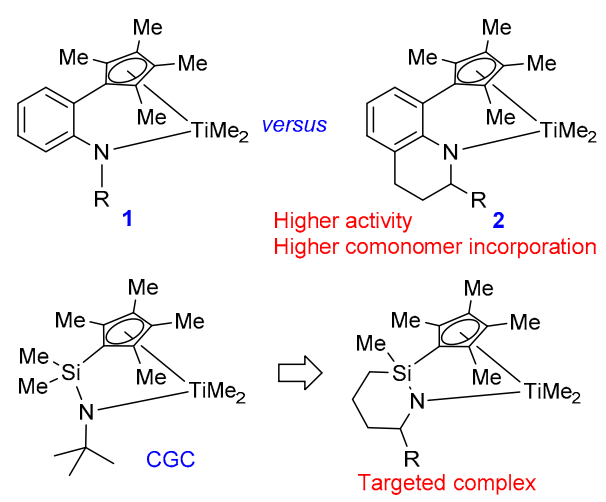

Chart 1. Ortho-phenylene-bridged half-metallocene complexes and the complexes targeted in this work.

\section{Results}

\subsection{Synthesis and Characterization}

The present strategy for construction of the [1,2]azasilinane framework involves the ring closure metathesis (RCM) of the two olefin units attached to the nitrogen and silicon atoms (Scheme 1). The precursor (3, $\mathrm{Me}_{4} \mathrm{C}_{5} \mathrm{H}-\mathrm{Si}(\mathrm{Me})\left(\mathrm{CH}_{2} \mathrm{CH}=\mathrm{CH}_{2}\right)-\mathrm{NH}\left(\mathrm{CH}_{2} \mathrm{CH}=\mathrm{CH}_{2}\right)$ ) for $\mathrm{RCM}$ was easily prepared according to the scheme applied in the construction of the prototype CGC ligand by using commercially available chemicals, tetramethylcyclopentadiene $\left(\mathrm{Me}_{4} \mathrm{C}_{5} \mathrm{H}_{2}\right)$, allyl(dichloro)methylsilane $\left(\left(\mathrm{CH}_{2}=\mathrm{CHCH}_{2}\right)(\mathrm{Me}) \mathrm{SiCl}_{2}\right)$, and allylamine. Initial RCM trials of 3 using Ru-catalysts (Grubbs 1st and 2nd generation catalysts and Hoveyda-Grubbs catalyst) for the synthesis of 6 were unsuccessful [40]. No ethylene gas was detected in the reaction monitored by ${ }^{1} \mathrm{H}-\mathrm{NMR}$. Instead, migration of the double bond in the allylamine unit was observed. In contrast, the Mo-catalyst (Schrock catalyst, $2 \mathrm{~mol} \%$ ) cleanly converted 3 to the desired cyclic compound 6 [41-44]. When a closed-NMR tube with $\mathrm{C}_{6} \mathrm{D}_{6}$ was used, the signal of generated ethylene was observed at $5.24 \mathrm{ppm}$ and the vinyl signals that were observed in the spectrum of 3 at $4.8-5.2 \mathrm{ppm}$ and 5.7-5.9 ppm completely disappeared, while two new $=\mathrm{CH}$ signals were observed at 5.8 and $5.5 \mathrm{ppm}$ (Figure 1). The RCM product 6 could be separated from the Mo-catalyst by vacuum distillation at $60^{\circ} \mathrm{C}$. The derivatives bearing methyl substituents at the $\alpha$-position of the amino group (7 and 8) were also successfully prepared by RCM of the corresponding precursors 4 and 5 , which were prepared using 1-methylallylamine or 1,1-dimethylallylamine instead of allylamine. Hydrogenation of $\mathbf{6}$ using a Pd/C catalyst afforded 9 bearing the desired [1,2]azasilinane framework; the double bonds in the tetramethylcyclopentadiene units remained intact during the hydrogenation process. The characteristic vinyl signals in the ${ }^{1} \mathrm{H}-\mathrm{NMR}$ spectrum of 6 completely disappeared after hydrogenation. However, hydrogenation of the derivatives 7 and 8 bearing methyl substituent(s) at the $\alpha$-position of the amino group was unsuccessful; the substrates remained intact under the identical hydrogenation conditions using the $\mathrm{Pd} / \mathrm{C}$ catalyst. 
The five-membered analogue $\mathbf{1 1}$ was also successfully prepared via RCM of the vinylsilane derivative using the same Mo catalyst. Hydrogenation of $\mathbf{1 1}$ using the Pd/C catalyst was also successful to afford 12 bearing the [1,2]azasilolidine framework (Scheme 1).
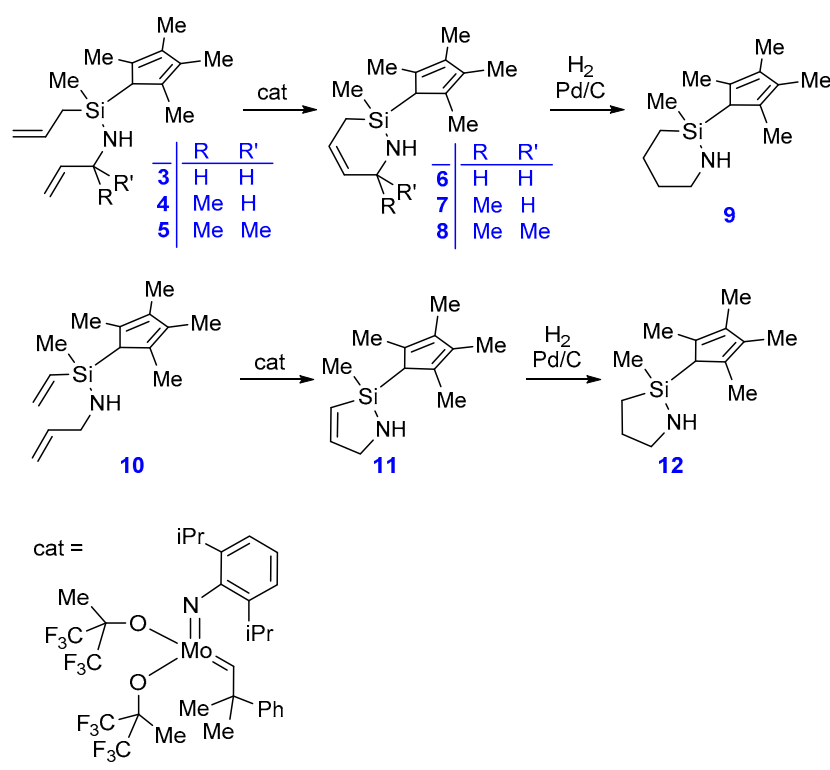

Scheme 1. Construction of the ligand frameworks for the targeted complexes.

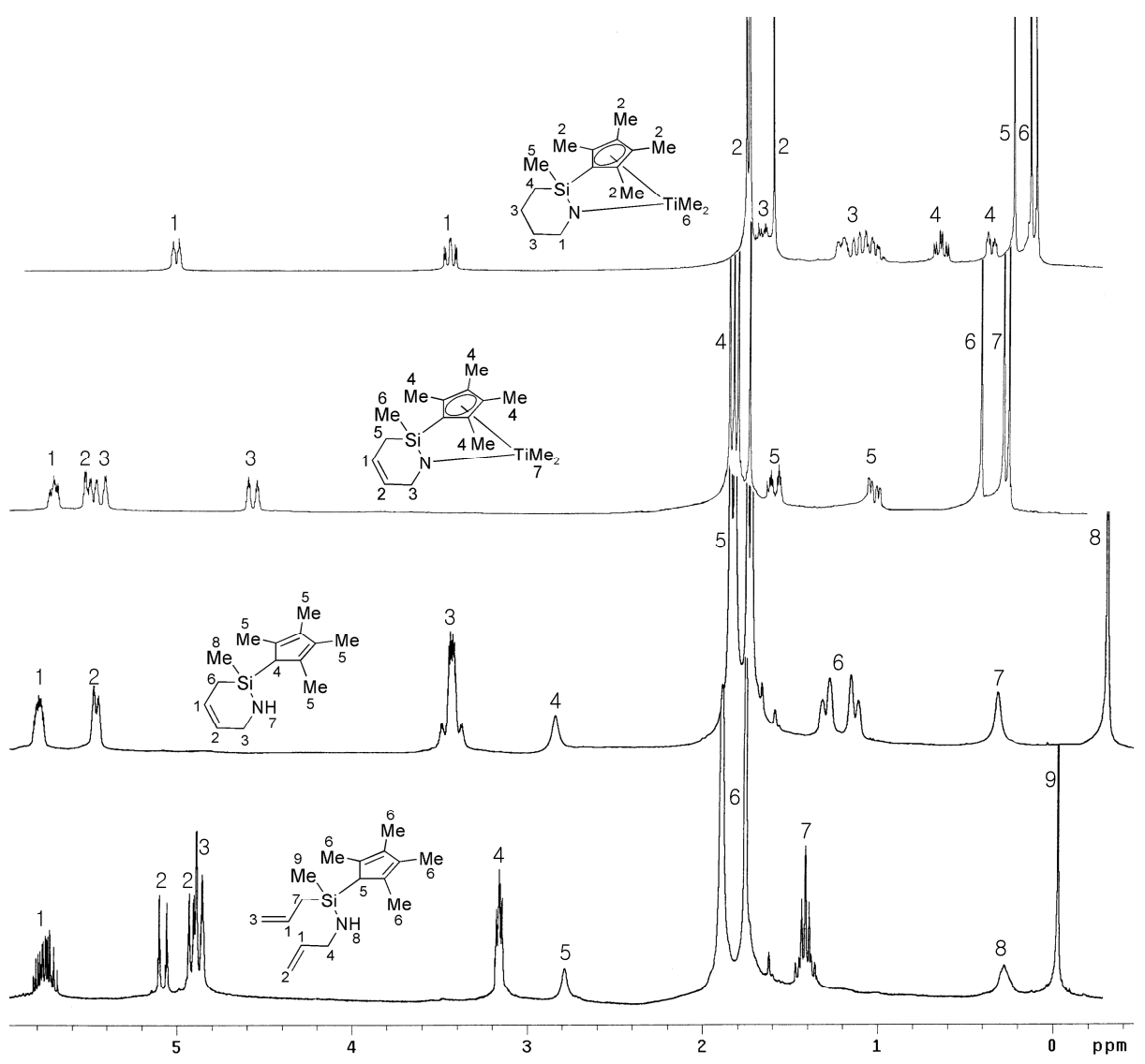

Figure 1. ${ }^{1} \mathrm{H}-\mathrm{NMR}$ spectra of ring closure metathesis (RCM) precursor (3), RCM product (6), and titanium complexes (13 and 14). 
The metalation of $\mathbf{6}$ using the methods introduced by Resconi et al. (treatment of 4 equiv. of MeLi in diethyl ether then with $\mathrm{TiCl}_{4}$ ) was unsuccessful $[45,46]$. The action of MeLi on 6 did not afford the desired dilithium compound $\left(\mathrm{MeC}_{5}(\mathrm{Li})-\mathrm{Si}(\mathrm{Me})\left(\mathrm{CH}_{2} \mathrm{CH}=\mathrm{CH}_{2}\right)-\mathrm{N}(\mathrm{Li})\left(\mathrm{CH}_{2} \mathrm{CH}=\mathrm{CH}_{2}\right)\right)$, but instead resulted in destruction of the ligand framework. However, treatment of 6 with 4 equiv. of $\mathrm{MeMgCl}$ for a rather long reaction time (three days) in tetrahydrofuran (THF) at room temperature cleanly generated the desired dianion $\left(\mathrm{MeC}_{5}(\mathrm{MgCl})-\mathrm{Si}(\mathrm{Me})\left(\mathrm{CH}_{2} \mathrm{CH}=\mathrm{CH}_{2}\right)-\mathrm{N}(\mathrm{MgCl})\left(\mathrm{CH}_{2} \mathrm{CH}=\mathrm{CH}_{2}\right)\right)$. Addition of $\mathrm{TiCl}_{4}(\mathrm{DME})$ to the resulting solution containing the dianionic species and remaining 2 equiv. of $\mathrm{MeMgCl}$ afforded the desired complex 13 (Chart 2) in moderate yield (63\%). The ${ }^{1} \mathrm{H}-\mathrm{NMR}$ spectrum showed Ti-Me and Si-Me signals at 0.59, 0.46, and $0.43 \mathrm{ppm}$ as singlets, while $\mathrm{C}_{5} \mathrm{Me}_{4}$-signals were observed at $1.98,1.96,1.94$, and $1.87 \mathrm{ppm}$ as singlets. The two protons on $-\mathrm{NCH}_{2}$ - are diastereotopic to each other and their signals were widely separated at 5.47 and $4.63 \mathrm{ppm}$ with a large geminal coupling constant $\left({ }^{2} J=19.5 \mathrm{~Hz}\right)$. The two $=\mathrm{CH}$ signals were observed at 5.7 and $5.5 \mathrm{ppm}$ as multiplets (Figure 1). Complex 14 was also successfully prepared from 9 (hydrogenated compound of 6) by the same method under the same conditions (treatment with 4 equiv. of $\mathrm{MeMgCl}$ and subsequent addition of $\mathrm{TiCl}_{4}(\mathrm{DME})$ ). The ${ }^{1} \mathrm{H}-\mathrm{NMR}$ spectrum of 14 (Figure 1) shows signals of the two diastereotopic $-\mathrm{NCH}_{2}$ - protons at 5.18 and $3.65 \mathrm{ppm}$, indicating a notable up-field shift relative to the corresponding chemical shifts of 13 (5.47 and $4.63 \mathrm{ppm}$ ). When 7 (RCM precursor bearing a methyl substituent at the $\alpha$-position of the amino group) was treated with $\mathrm{MeMgCl}$, deprotonation was sluggish. Treatment of 2 equiv. of $n \mathrm{BuLi}$ in diethyl ether cleanly precipitated the dilithium compound, which was subsequently treated with $\mathrm{TiCl}_{4}(\mathrm{DME})$ and 2 equiv. of $\mathrm{MeMgCl}$ simultaneously to afford the desired titanium complex 15. Having two chiral centers, 15 was obtained as a mixture of two diastereomers and the ${ }^{1} \mathrm{H}$ - and ${ }^{13} \mathrm{C}$-NMR signals were rather complex. Titanium complexes $\mathbf{1 6}$ and $\mathbf{1 7}$ were successfully generated from the respective RCM precursors 3 and 10. In these cases, treatment of $n \mathrm{BuLi}$ in diethyl ether cleanly precipitated the corresponding dilithium compounds, from which the desired complexes were generated in good yields $\left(84 \%\right.$ and $88 \%$ ) by treatment with $\mathrm{TiCl}_{4}(\mathrm{DME})$ and 2 equiv. of $\mathrm{MeMgCl}$. The vinyl groups in 17 were hydrogenated using a Pd/C catalyst to obtain $18\left(\left[\mathrm{Me}(\mathrm{Et}) \mathrm{Si}\left(\eta^{5}-\mathrm{Me}_{4} \mathrm{C}_{5}\right)\left(\kappa^{1}-\mathrm{NPr}\right)\right] \mathrm{TiMe}_{2}\right)$. All complexes, except for $\mathbf{1 4}$, were oily in nature with high solubility in hexane, and resistant to recrystallization, but the crude products extracted using hexane were pure based on ${ }^{1} \mathrm{H}$ - and ${ }^{13} \mathrm{C}-\mathrm{NMR}$ analyses. Complex 14 was crystalline, but the crystals were formed as thin needles that were unsuitable for X-ray crystallography.
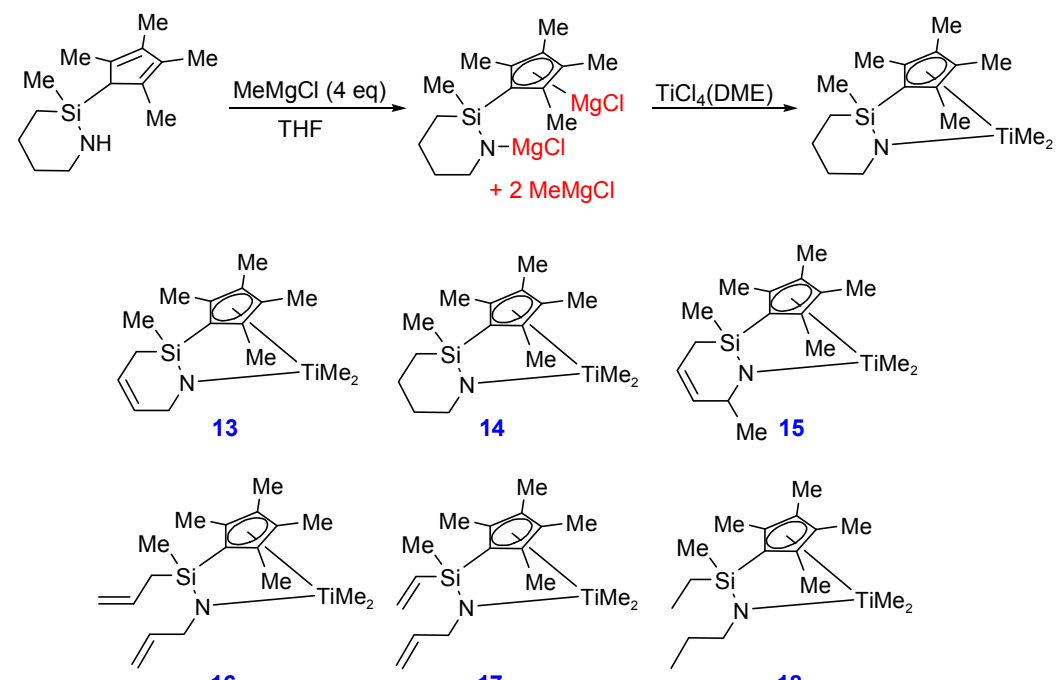

Chart 2. Prepared Ti-complexes.

In the case of 8 (compounds bearing two methyl substituents at the $\alpha$-position), treatment of $n \mathrm{BuLi}$ in diethyl ether cleanly precipitated the desired dilithium compound as a white solid, but metallation 
was unsuccessful. In the cases of $\mathbf{1 1}$ and $\mathbf{1 2}$ (five-membered ring compounds), various metallation attempts were also unsuccessful. In another route, RCM of the titanium complex $\mathbf{1 7}$ bearing vinyl-Si and allyl-N groups was also unsuccessfully attempted. In contrast, RCM of the titanium complex 16 bearing allyl-Si and allyl-N groups using the Mo-catalyst successfully generated six-membered ring complex 13 (Scheme 2). The bite angle in the cases of the five membered ring species 11 and 12 may not be practicable for chelation.
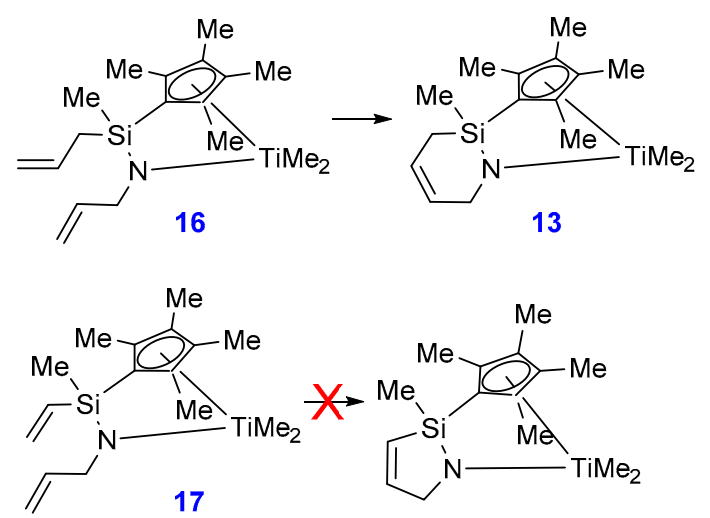

Scheme 2. Ring closure metathesis (RCM) of the titanium complexes.

\subsection{Polymerization Studies}

The newly prepared complexes 13-18 along with the prototype CGC $\left[\mathrm{Me}_{2} \mathrm{Si}\left(\eta^{5}-\mathrm{Me}_{4} \mathrm{C}_{5}\right)\left(\mathrm{N}^{t} \mathrm{Bu}\right)\right] \mathrm{TiMe}_{2}$ as a comparison were screened for ethylene/1-octene copolymerization in aliphatic hydrocarbon solvent (methylcyclohexane) after activation with $\left[\mathrm{Ph}_{3} \mathrm{C}\right]\left[\mathrm{B}\left(\mathrm{C}_{6} \mathrm{~F}_{5}\right)_{4}\right]$. Triisobutylaluminum $\left(\mathrm{iBu} \mathrm{Al}_{3}\right)$ was used as a scavenger and the temperature was controlled in the range of $130-150{ }^{\circ} \mathrm{C}$. The polymerization results are summarized in Table 1 . None of the newly prepared complexes exhibited activity superior to that of CGC (entries 1-6 versus entry 7). The highest activity was observed with 15, but the activity was $\sim 2 / 3$ that of CGC $\left(3.1 \times 10^{6}\right.$ versus $\left.5.0 \times 10^{6} \mathrm{~g} / \mathrm{mol}-\mathrm{Ti}\right)$. The activities of 13 and 14 were $\sim 1 / 3$ that of CGC, while the activity of 18 was $\sim 1 / 2$ that of CGC. Complexes 16 and 17 containing acyclic olefin units showed low activity $(<1 / 4$ that of CGC).

Table 1. Ethylene/1-octene copolymerization results ${ }^{\mathrm{a}}$.

\begin{tabular}{|c|c|c|c|c|c|c|c|c|}
\hline Entry & Cat & Scavenger & Temperature $\left({ }^{\circ} \mathrm{C}\right)$ & Yield (g) & Activity ${ }^{b}$ & $\begin{array}{c}{[\text { Oct }]^{c}} \\
(\mathrm{~mol} \%)\end{array}$ & $\begin{array}{c}M_{\mathrm{n}} \\
(\mathrm{kDa})\end{array}$ & $M_{\mathrm{w}} / M_{\mathrm{n}}$ \\
\hline 1 & 13 & $\mathrm{iBu}_{3} \mathrm{Al}$ & $129-139-134$ & 0.91 & 1.82 & 12 & 69.4 & 2.02 \\
\hline 2 & 14 & $\mathrm{iBu}_{3} \mathrm{Al}$ & $130-142-135$ & 0.89 & 1.78 & 14 & 50.4 & 2.14 \\
\hline 3 & 15 & $\mathrm{iBu}_{3} \mathrm{Al}$ & $129-147$ (50 sec)-137 & 1.54 & 3.08 & 11 & 43.0 & 2.17 \\
\hline 4 & 16 & $\mathrm{iBu}_{3} \mathrm{Al}$ & $129-132-129$ & 0.42 & 0.84 & 14 & 108 & 2.18 \\
\hline 5 & 17 & $\mathrm{iBu}_{3} \mathrm{Al}$ & 129-136-135 & 0.61 & 1.22 & 15 & 105 & 2.30 \\
\hline 6 & 18 & $\mathrm{iBu}_{3} \mathrm{Al}$ & $129-144(40 \mathrm{sec})-137$ & 1.19 & 2.38 & 19 & 72.4 & 1.97 \\
\hline 7 & CGC & $\mathrm{iBu}_{3} \mathrm{Al}$ & $120-143(25 \mathrm{sec})-125$ & 2.48 & 4.96 & 21 & 17.0 & 4.41 \\
\hline 8 & 13 & {$\left[\mathrm{iBu}_{2} \mathrm{Al}\right]_{2} \mathrm{O}$} & $129-148-142$ & 1.53 & 3.06 & 14 & 44.8 & 2.17 \\
\hline 9 & 14 & {$\left[\mathrm{iBu}_{2} \mathrm{Al}\right]_{2} \mathrm{O}$} & $128-153(40 \mathrm{sec})-146$ & 2.36 & 4.72 & 15 & 35.6 & 2.27 \\
\hline 10 & 14 & {$\left[\mathrm{iBu}_{2} \mathrm{Al}\right]_{2} \mathrm{O}$} & $80-112(60 \mathrm{sec})-113$ & 3.28 & 6.55 & 15 & 203 & 2.16 \\
\hline 11 & 15 & {$\left[\mathrm{iBu}_{2} \mathrm{Al}\right]_{2} \mathrm{O}$} & $129-154-150$ & 2.75 & 5.50 & 13 & 26.1 & 2.22 \\
\hline 12 & 16 & {$\left[\mathrm{iBu}_{2} \mathrm{Al}\right]_{2} \mathrm{O}$} & $128-136-133$ & 0.90 & 1.80 & 14 & 107 & 2.31 \\
\hline 13 & 17 & {$\left[\mathrm{iBu}_{2} \mathrm{Al}\right]_{2} \mathrm{O}$} & $129-137-133$ & 1.01 & 2.02 & 16 & 105 & 2.17 \\
\hline 14 & 18 & {$\left[\mathrm{iBu}_{2} \mathrm{Al}\right]_{2} \mathrm{O}$} & $128-147$ (50 sec)-138 & 1.73 & 3.46 & 20 & 68.8 & 1.90 \\
\hline 15 & CGC & {$\left[\mathrm{iBu}_{2} \mathrm{Al}\right]_{2} \mathrm{O}$} & $120-154(50 \mathrm{sec})-134$ & 3.58 & 7.15 & 21 & 9.3 & 6.87 \\
\hline 16 & CGC & {$\left[\mathrm{iBu}_{2} \mathrm{Al}\right]_{2} \mathrm{O}$} & $80-121$ (35 sec)-108 & 4.20 & 8.40 & 36 & 33.7 & 1.91 \\
\hline
\end{tabular}

${ }^{a}$ Polymerization conditions: methylcyclohexane solution $(25 \mathrm{~mL})$ containing 1-octene $(3.0 \mathrm{~g}), 0.5 \mu \mathrm{mol} \mathrm{Ti}, 2.0 \mu \mathrm{mol}$ $\left[\mathrm{Ph}_{3} \mathrm{C}\right]\left[\mathrm{B}\left(\mathrm{C}_{6} \mathrm{~F}_{5}\right)_{4}\right]$, scavenger $(0.20 \mathrm{mmol}-\mathrm{Al})$, ethylene ( $\left.30 \mathrm{bar}\right), 3 \mathrm{~min} .{ }^{\mathrm{b}}$ Activity in unit of $10^{6} \mathrm{~g} / \mathrm{mol}-\mathrm{Ti}$. ${ }^{\mathrm{c}} 1$-Octene content in the copolymer determined by ${ }^{1} \mathrm{H}-\mathrm{NMR}$. 
Advantageously, the molecular weights of the products were higher than that of the polymer generated with CGC. Under the polymerization conditions employing methylcyclohexane at high temperature $\left(120-150{ }^{\circ} \mathrm{C}\right)$, CGC produced relatively low-molecular-weight polymer $\left(M_{\mathrm{n}}, 17 \mathrm{kDa}\right)$ with a rather broad molecular weight distribution $\left(M_{\mathrm{w}} / M_{\mathrm{n}} 4.41\right)$, in contrast with the narrow molecular weight distributions $\left(M_{\mathrm{w}} / M_{\mathrm{n}}\right.$ 1.7-3.4) obtained when the polymerization was performed in toluene at lower temperature $\left(70-90^{\circ} \mathrm{C}\right)[25,27,47]$. In this study, a bimodal molecular weight distribution was observed for CGC with the low molecular weight portion comprising a main modal and the high molecular weight portion being a shoulder (Figure 2). All other complexes (13-18) except for CGC produced polymers with a narrow molecular weight distribution $\left(M_{\mathrm{w}} / M_{\mathrm{n}} 2.0-2.3\right)$. Among complexes 13-18, 15 (bearing a methyl substituent at the $\alpha$-carbon of the amido ligand) had the highest activity and also exhibited the lowest molecular weight $\left(M_{n}, 43 \mathrm{kDa}\right)$. Complexes 13, 14 and 18 produced relatively high molecular weight polymers $\left(M_{n}, 50-70 \mathrm{kDa}\right)$ with reasonably high activities. Complexes 16 and 17 produced the highest molecular weight polymers $\left(M_{n}, 110 \mathrm{kDa}\right)$, although their activities were low. Because of its low molecular weight, the polymer generated by CGC was sticky, in contrast with other generated polymers.

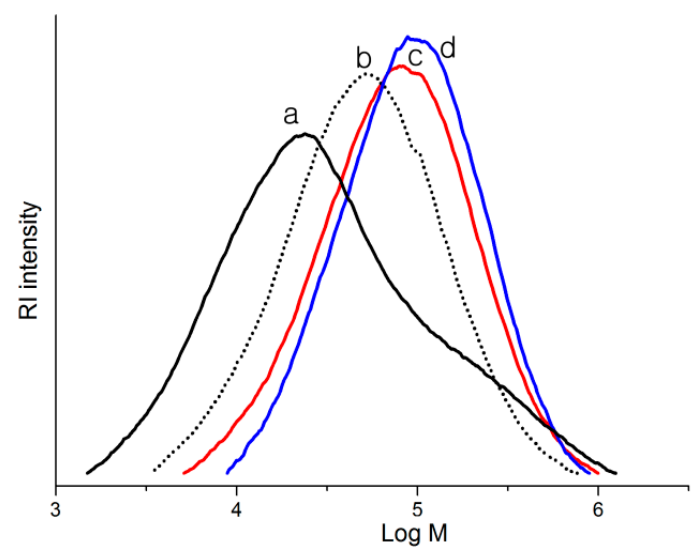

Figure 2. Gel permeation chromatography (GPC) curves of polymers generated with constrainedgeometry catalyst $(\mathrm{CGC}) /\left[\mathrm{Ph}_{3} \mathrm{C}\right]\left[\mathrm{B}\left(\mathrm{C}_{6} \mathrm{~F}_{5}\right)_{4}\right] / \mathrm{iBu}_{3} \mathrm{Al}$ (a, entry 7), $\mathbf{1 4}(\mathbf{b}), \mathbf{1 3}(\mathbf{c})$, and $\mathbf{1 8}(\mathbf{d})$ activated with $\left[\mathrm{Ph}_{3} \mathrm{C}\right]\left[\mathrm{B}\left(\mathrm{C}_{6} \mathrm{~F}_{5}\right)_{4}\right] /\left[\mathrm{iBu}_{2} \mathrm{Al}_{2} \mathrm{O}\right.$.

It was postulated that the low activities might be attributed to facile formation of "Ti( $\mu-\mathrm{R}) \mathrm{AlR}{ }_{2}$ "type heterobimetallic species due to the highly accessible reaction site. Such heterobimetallic species have been recognized to be generated as a dormant state in the olefin polymerization process [48,49]. In order to suppress formation of such dormant species, Busico and coworkers treated MAO with 2,6-di-tert-butylphenol with the aim to trap free $\mathrm{Me}_{3} \mathrm{Al}$ contained in $\mathrm{MAO}$, and Soares and coworkers used highly bulky trioctylaluminum as a scavenger [50-52]. In this study, we explored the use of tetrabutylaluminoxane $\left(\left[\mathrm{iBu}_{2} \mathrm{Al}\right]_{2} \mathrm{O}\right)$ instead of $\mathrm{iBu}_{3} \mathrm{Al}$ as a scavenger. $\left[\mathrm{iBu}_{2} \mathrm{Al}\right]_{2} \mathrm{O}$ is a commercially available chemical that is easily synthesized from $\mathrm{iBu}_{3} \mathrm{Al}$ by treatment with water [53,54]. By employing $\left[\mathrm{iBu}_{2} \mathrm{Al}\right]_{2} \mathrm{O}$ as a scavenger instead of $\mathrm{iBu}_{3} \mathrm{Al}$, the activity was improved in all cases (entries 1-7 versus $8-16)$. The improvement was most significant in the case of $\mathbf{1 4}$, where the activity improved 2.7-fold to reach $4.7 \times 10^{6} \mathrm{~g} / \mathrm{mol}-\mathrm{Ti}$, which is comparable to that of $\mathrm{CGC} /\left[\mathrm{Ph}_{3} \mathrm{C}\right]\left[\mathrm{B}\left(\mathrm{C}_{6} \mathrm{~F}_{5}\right)_{4}\right] / \mathrm{iBu}_{3} \mathrm{Al}$ $\left(5.0 \times 10^{6} \mathrm{~g} / \mathrm{mol}-\mathrm{Ti}\right)$. In the other cases, the activity improved $\sim 1.5$-fold. Both 14 and CGC were deactivated during the course of high temperature polymerization; the yields were marginally increased from $2.36 \mathrm{~g}$ (entry 9) to $2.56 \mathrm{~g}$ and from $3.58 \mathrm{~g}$ (entry 15) to $3.76 \mathrm{~g}$ for $\mathbf{1 4}$ and CGC, respectively, by lengthening the reaction time from $3 \mathrm{~min}$ to $6 \mathrm{~min}$.

The $M_{n}$ values declined somewhat with the use of $\left[\mathrm{iBu}_{2} \mathrm{Al}\right]_{2} \mathrm{O}$ instead of $\mathrm{iBu}_{3} \mathrm{Al}$, but the general trend of the molecular weight versus the catalyst structure was the same (Figure 2). In the cases of 14-18, the $M_{n}$ values decreased by a factor of $\sim 0.65$ upon replacement of the $\mathrm{iBu}_{3} \mathrm{Al}$ with $\left[\mathrm{iBu}_{2} \mathrm{Al}\right]_{2} \mathrm{O}$, 
while the decrease was marginal in the case of 18, which invariably produced high molecular weight polymers $\left(M_{n}, \sim 70 \mathrm{kDa}\right)$. The most significant decline of the $M_{\mathrm{n}}$ value was observed in the case of CGC, resulting in the production of a low-molecular-weight sticky polymer $\left(M_{n}, 9.3 \mathrm{kDa}\right)$ with bimodal molecular weight distribution.

Contrary to the expectation, the 1-octene contents of the samples generated using 13-17 were lower (12 mol \%-15 mol \%) than that of CGC (21 mol \%) (Entries 8-13 versus 15). In the case of 18, the 1-octene content was as high as that of CGC (19 $\mathrm{mol} \%$ and $21 \mathrm{~mol} \%$, respectively). Strangely, whereas the melting signals observed in the differential scanning calorimeter (DSC) thermogram of the samples generated with 13-18 were extremely weak, the melting signal was observed around $100{ }^{\circ} \mathrm{C}$ for the sample generated with CGC, although the 1-octene content was even higher (Figure 3). This observation and the bimodal molecular weight distribution together indicate that the comonomer composition may not be uniform for the sample generated with the prototype CGC under the present polymerization conditions. When the polymerization temperature was lowered $\left(80-120^{\circ} \mathrm{C}\right)$, a unimodal distribution was observed in the GCP curve and the 1-octene content was significantly higher (36 mol \%, entry 16). The melting signal was neither observed at DSC thermogram. These observations indicate that the prototype CGC generates another type of active species at high temperature, which produce high-molecular-weight polymer chains with less 1-octene content.

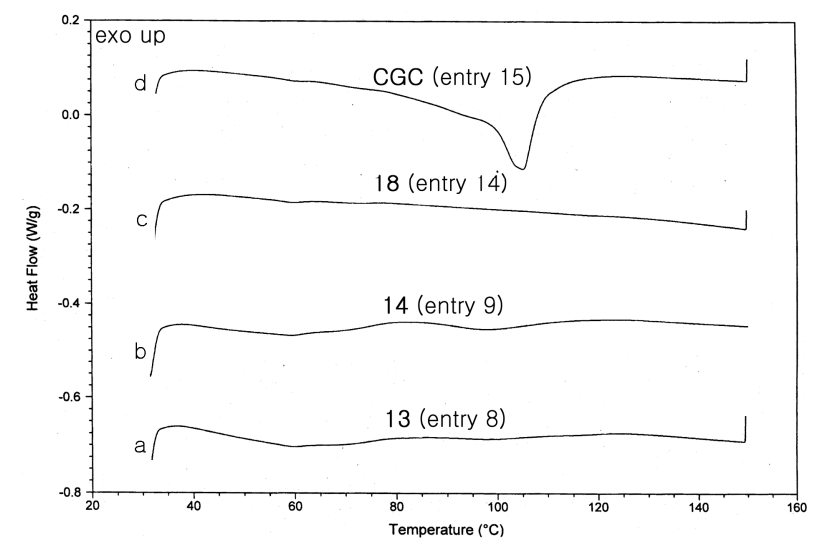

Figure 3. Differential scanning calorimeter (DSC) curves of the generated polymers.

\section{Experimental Section}

\subsection{General Remarks}

All manipulations were performed under an inert atmosphere using standard glovebox and Schlenk techniques. Toluene, hexane, THF and diethyl ether were distilled from benzophenone ketyl. Methylcyclohexane was purified using a Na-K Alloy. NMR spectra were recorded on a Varian Mercury plus 400 instrument (Varian, Inc., Palo Alto, CA, USA). Mass spectra were obtained with a Micromass VG Autospec apparatus. Gel permeation chromatograms (GPC) were obtained at $140{ }^{\circ} \mathrm{C}$ in trichlorobenzene using a Waters Model 150-C+ GPC instrument (Waters, Milford, MA, USA) and the data were analyzed using a polystyrene analysis curve. 1-Methylallylamine and 1,1-dimethylallylamine were prepared by the procedure reported in the literature $[55,56]$.

\subsection{Compound 3}

Allyl(dichloro)methylsilane $\left(\left(\mathrm{CH}_{2}=\mathrm{CHCH}_{2}\right)(\mathrm{Me}) \mathrm{SiCl}_{2}\right)(1.63 \mathrm{~g}, 10.5 \mathrm{mmol})$ was added dropwise to a stirred solution of tetramethylcyclopentadienyllithium $(0.897 \mathrm{~g}, 7.0 \mathrm{mmol})$ in THF $(40 \mathrm{~mL})$ at $-78^{\circ} \mathrm{C}$. The solution was stirred overnight at room temperature. All the volatiles were removed under vacuum, and hexane $(30 \mathrm{~mL})$ was then added in a glove box. The insoluble fraction was removed by filtration with the aid of Celite. Solvent in the filtrate was removed under vacuum and the resulting 
crude oil was distilled under full vacuum at $60^{\circ} \mathrm{C}$ to obtain $\left(\mathrm{CH}_{2}=\mathrm{CHCH}_{2}\right)(\mathrm{Me}) \mathrm{Si}\left(\mathrm{C}_{5} \mathrm{Me}_{4}\right) \mathrm{Cl}(1.49 \mathrm{~g}$, 88\%). ${ }^{1} \mathrm{H}-\mathrm{NMR}\left(\mathrm{C}_{6} \mathrm{D}_{6}\right): \delta 5.76-5.65(\mathrm{~m}, 1 \mathrm{H}, \mathrm{CH}=), 4.95-4.87\left(\mathrm{~m}, 2 \mathrm{H},=\mathrm{CH}_{2}\right), 2.94\left(\mathrm{~b}, 1 \mathrm{H}, \mathrm{C}_{5} \mathrm{H}\right), 1.95(\mathrm{~s}$, $\left.3 \mathrm{H}, \mathrm{CH}_{3}\right), 1.88\left(\mathrm{~s}, 3 \mathrm{H}, \mathrm{CH}_{3}\right), 1.70\left(\mathrm{~s}, 6 \mathrm{H}, \mathrm{CH}_{3}\right), 1.61\left(\mathrm{dd}, J=13.6,7.6 \mathrm{~Hz}, 1 \mathrm{H}, \mathrm{SiCH}_{2}\right), 1.51(\mathrm{dd}, J=13.6$, $\left.7.6 \mathrm{~Hz}, 1 \mathrm{H}, \mathrm{SiCH}_{2}\right), 0.19\left(\mathrm{~s}, 3 \mathrm{H}, \mathrm{SiCH}_{3}\right) \mathrm{ppm} .{ }^{13} \mathrm{C}\left\{{ }^{1} \mathrm{H}\right\}-\mathrm{NMR}\left(\mathrm{C}_{6} \mathrm{D}_{6}\right): \delta 128.04,137.78,132.50,131.46$, $130.94,115.26,55.52,23.62,14.63,14.60,11.47,11.41,-0.84 \mathrm{ppm}$. High resolution mass (HRMS) (EI): $\mathrm{m} / \mathrm{z}$ calcd. ([M] $\left.{ }^{+} \mathrm{C}_{13} \mathrm{H}_{21} \mathrm{ClSi}\right) 240.1099$. Found: 240.1101. $\left(\mathrm{CH}_{2}=\mathrm{CHCH}_{2}\right)(\mathrm{Me}) \mathrm{Si}\left(\mathrm{C}_{5} \mathrm{Me}_{4}\right) \mathrm{Cl}(1.49 \mathrm{~g}$, $6.50 \mathrm{mmol})$ dissolved in THF $(15 \mathrm{~mL})$ was added dropwise to a stirred solution of $\mathrm{LiN}(\mathrm{H}) \mathrm{CH}_{2} \mathrm{CH}=\mathrm{CH}_{2}$ $(0.450 \mathrm{~g}, 7.15 \mathrm{mmol})$ in THF $(25 \mathrm{~mL})$ at $-78^{\circ} \mathrm{C}$ and the resulting solution was stirred overnight at room temperature. The volatiles were removed under vacuum and hexane $(20 \mathrm{~mL})$ was then added in a glove box. The insoluble fraction was removed by filtration with the aid of Celite. Solvent in the filtrate was removed under vacuum and the resulting crude oil was distilled under full vacuum at $70{ }^{\circ} \mathrm{C}$ (1.16 g, 73\%). ${ }^{1} \mathrm{H}-\mathrm{NMR}\left(\mathrm{C}_{6} \mathrm{D}_{6}\right): 5.86-5.73(\mathrm{~m}, 2 \mathrm{H}, \mathrm{CH}=), 5.13\left(\mathrm{ddd}, J=17.2,3.6,1.6 \mathrm{~Hz}, 1 \mathrm{H},=\mathrm{CH}_{2}\right), 4.97$ $\left(\mathrm{ddd}, J=4.4,3.6,1.6 \mathrm{~Hz}, 1 \mathrm{H},=\mathrm{CH}_{2}\right), 4.95-4.90\left(\mathrm{~m}, 2 \mathrm{H},=\mathrm{CH}_{2}\right), 3.25-3.20\left(\mathrm{~m}, 2 \mathrm{H}, \mathrm{NCH}_{2}\right), 2.85(\mathrm{~b}, 1 \mathrm{H}$, $\left.\mathrm{C}_{5} \mathrm{H}\right), 1.97\left(\mathrm{~s}, 3 \mathrm{H}, \mathrm{CH}_{3}\right), 1.96\left(\mathrm{~s}, 3 \mathrm{H}, \mathrm{CH}_{3}\right), 1.83\left(\mathrm{~s}, 6 \mathrm{H}, \mathrm{CH}_{3}\right), 1.54-1.43\left(\mathrm{~m}, 2 \mathrm{H}, \mathrm{SiCH}_{2}\right), 0.35(\mathrm{~b}, 1 \mathrm{H}, \mathrm{NH})$, $0.05\left(\mathrm{~s}, 3 \mathrm{H}, \mathrm{SiCH}_{3}\right)$ ppm. ${ }^{13} \mathrm{C}\left\{{ }^{1} \mathrm{H}\right\}-\mathrm{NMR}\left(\mathrm{C}_{6} \mathrm{D}_{6}\right): \delta 140.56,135.78,135.68,135.18,132.55,132.25,113.27$, $112.81,55.52,44.92,22.44,14.78,11.52,-3.96$ ppm. HRMS (EI): $\mathrm{m} / z$ calcd ([M] $\left.{ }^{+} \mathrm{C}_{16} \mathrm{H}_{27} \mathrm{NSi}\right) 261.1913$. Found: 261.1909.

\subsection{Compound 4}

1-Methylallylamine $(0.950 \mathrm{~g}, 13.3 \mathrm{mmol})$ was added to $\left(\mathrm{CH}_{2}=\mathrm{CHCH}_{2}\right)(\mathrm{Me}) \mathrm{Si}\left(\mathrm{C}_{5} \mathrm{Me}_{4}\right) \mathrm{Cl}(1.27 \mathrm{~g}$, $5.3 \mathrm{mmol})$ in THF $(20 \mathrm{~mL})$ and the resulting solution was stirred for $20 \mathrm{~h}$. All volatiles were removed under vacuum and hexane $(15 \mathrm{~mL})$ was added. The generated $\mathrm{HCl}$-allylamine salt was removed by filtration. Solvent in the filtrate was removed under vacuum to obtain colorless oil ( $1.38 \mathrm{~g}, 94 \%)$. The ${ }^{1} \mathrm{H}$-NMR spectrum indicated a mixture of two diastereomers in ca. 1:1 ratio. ${ }^{1} \mathrm{H}-\mathrm{NMR}\left(\mathrm{C}_{6} \mathrm{D}_{6}\right)$ : $\delta 5.86-5.71(\mathrm{~m}, 2 \mathrm{H}, \mathrm{CH}=), 5.03\left(\mathrm{ddt}, J=17.2,12.0,1.6 \mathrm{~Hz}, 1 \mathrm{H},=\mathrm{CH}_{2}\right), 4.92-4.86\left(\mathrm{~m}, 3 \mathrm{H},=\mathrm{CH}_{2}\right)$, 3.36-3.29 (m, 1H, NCH), $2.84\left(\mathrm{~b}, 1 \mathrm{H}, \mathrm{C}_{5} \mathrm{H}\right), 1.97\left(\mathrm{~s}, 3 \mathrm{H}, \mathrm{CH}_{3}\right), 1.95\left(\mathrm{~s}, 3 \mathrm{H}, \mathrm{CH}_{3}\right), 1.81\left(\mathrm{~s}, 6 \mathrm{H}, \mathrm{CH}_{3}\right), 1.49$ $\left(\mathrm{m}, 2 \mathrm{H}, \mathrm{SiCH}_{2}\right), 1.04$ and $1.02\left(\mathrm{~s}, 3 \mathrm{H}, \mathrm{NCCH}_{3}\right), 0.31$ and $0.28(\mathrm{~b}, 1 \mathrm{H}, \mathrm{NH}), 0.12\left(\mathrm{~s}, 3 \mathrm{H}, \mathrm{SiCH}_{3}\right) \mathrm{ppm}$. ${ }^{13} \mathrm{C}\left\{{ }^{1} \mathrm{H}\right\}-\mathrm{NMR}\left(\mathrm{C}_{6} \mathrm{D}_{6}\right): \delta 145.83$ and $145.76,135.82,135.68,135.35$ and $135.31,132.71,132.27,113.28$ and 113.25, 111.18 and 111.16, 55.69 and 55.59, 49.98 and 49.88, 25.80 and 25.72, 23.18 and 23.00, 15.06, 14.95, 11.54, $-2.72 \mathrm{ppm}$. HRMS (EI): $m / z$ calcd ([M] $\left.{ }^{+} \mathrm{C}_{17} \mathrm{H}_{29} \mathrm{NSi}\right)$ 275.2069. Found: 275.2071.

\subsection{Compound 5}

It was prepared by using the same procedure as utilized for 4 by using 1,1-dimethylallylamine (1.41 g, 91\%). ${ }^{1} \mathrm{H}-\mathrm{NMR}\left(\mathrm{C}_{6} \mathrm{D}_{6}\right): \delta 5.90(\mathrm{dd}, J=17.2,10.4 \mathrm{~Hz}, 1 \mathrm{H}, \mathrm{CH}=), 5.84-5.77(\mathrm{~m}, 1 \mathrm{H}, \mathrm{CH}=), 5.04(\mathrm{dd}$, $\left.J=17.2,1.4 \mathrm{~Hz}, 1 \mathrm{H},=\mathrm{CH}_{2}\right), 4.96-4.90\left(\mathrm{~m}, 2 \mathrm{H},=\mathrm{CH}_{2}\right), 4.86\left(\mathrm{dd}, J=10.4,1.4 \mathrm{~Hz}, 1 \mathrm{H},=\mathrm{CH}_{2}\right), 2.90(\mathrm{~s}$, $\left.1 \mathrm{H}, \mathrm{C}_{5} \mathrm{H}\right), 2.05\left(\mathrm{~s}, 3 \mathrm{H}, \mathrm{CH}_{3}\right), 1.98\left(\mathrm{~s}, 3 \mathrm{H}, \mathrm{CH}_{3}\right), 1.84\left(\mathrm{~s}, 3 \mathrm{H}, \mathrm{CH}_{3}\right), 1.83\left(\mathrm{~s}, 3 \mathrm{H}, \mathrm{CH}_{3}\right), 1.51(\mathrm{~d}, J=8.4 \mathrm{~Hz}$, $\left.2 \mathrm{H}, \mathrm{SiCH}_{2}\right), 1.15\left(\mathrm{~s}, 3 \mathrm{H}, \mathrm{NC}\left(\mathrm{CH}_{3}\right)_{2}\right), 1.14\left(\mathrm{~s}, 3 \mathrm{H}, \mathrm{NC}\left(\mathrm{CH}_{3}\right)_{2}\right), 0.56(\mathrm{~b}, 1 \mathrm{H}, \mathrm{NH}), 0.29\left(\mathrm{~s}, 3 \mathrm{H}, \mathrm{SiCH}_{3}\right)$ ppm. ${ }^{13} \mathrm{C}\left\{{ }^{1} \mathrm{H}\right\}-\mathrm{NMR}\left(\mathrm{C}_{6} \mathrm{D}_{6}\right): \delta 149.41,135.76,135.65,135.46,133.30,132.56,113.28,109.51,55.97,52.88$, $31.65,31.40,24.12,15.29,15.06,11.50,0.86 \mathrm{ppm}$. HRMS (EI): $\mathrm{m} / z$ calcd $\left([\mathrm{M}]^{+} \mathrm{C}_{18} \mathrm{H}_{31} \mathrm{NSi}\right) 289.2226$. Found: 289.2224 .

\subsection{Compound 6}

Compound $3(0.600 \mathrm{~g}, 2.29 \mathrm{mmol})$ in toluene $(10 \mathrm{~mL})$ was cooled to $-30{ }^{\circ} \mathrm{C}$ and the Schrock catalyst $(35 \mathrm{mg}, 0.046 \mathrm{mmol})$ dissolved in toluene $(1.0 \mathrm{~mL})$ was then added. During the course of the reaction, ethylene gas was generated and was removed through a bubbler. After stirring for $3 \mathrm{~h}$ at room temperature, all volatiles were removed under vacuum. The resulting crude oil was distilled under full vacuum at $60{ }^{\circ} \mathrm{C}(0.507 \mathrm{~g}, 95 \%) .{ }^{1} \mathrm{H}-\mathrm{NMR}\left(\mathrm{C}_{6} \mathrm{D}_{6}\right): \delta 5.88-5.82(\mathrm{~m}, 1 \mathrm{H}, \mathrm{CH}=), 5.54-5.51(\mathrm{~m}$, $1 \mathrm{H},=\mathrm{CH}), 3.58-3.46\left(\mathrm{~m}, 2 \mathrm{H}, \mathrm{NCH}_{2}\right), 2.93\left(\mathrm{~b}, 1 \mathrm{H}, \mathrm{C}_{5} \mathrm{H}\right), 1.95\left(\mathrm{~s}, 3 \mathrm{H}, \mathrm{CH}_{3}\right), 1.92\left(\mathrm{~s}, 3 \mathrm{H}, \mathrm{CH}_{3}\right), 1.85(\mathrm{~s}, 3 \mathrm{H}$, $\left.\mathrm{CH}_{3}\right), 1.83\left(\mathrm{~s}, 3 \mathrm{H}, \mathrm{CH}_{3}\right), 1.41\left(\mathrm{~d}, J=16.0 \mathrm{~Hz}, 1 \mathrm{H}, \mathrm{SiCH}_{2}\right), 1.25\left(\mathrm{~d}, J=16.0 \mathrm{~Hz}, 1 \mathrm{H}, \mathrm{SiCH}_{2}\right), 0.65(\mathrm{~b}, 1 \mathrm{H}$, 
$\mathrm{NH}),-0.18\left(\mathrm{~s}, 3 \mathrm{H}, \mathrm{SiCH}_{3}\right)$ ppm. ${ }^{13} \mathrm{C}\left\{{ }^{1} \mathrm{H}\right\}-\mathrm{NMR}\left(\mathrm{C}_{6} \mathrm{D}_{6}\right): \delta 135.42,132.19,128.27,123.66,56.53,43.31$, 14.46, 11.89, 11.48, -4.33 ppm. HRMS (EI): $\mathrm{m} / z$ calcd ([M] ${ }^{+} \mathrm{C}_{14} \mathrm{H}_{23} \mathrm{NSi}$ ) 233.1600. Found: 233.1597.

\subsection{Compound 7}

It was prepared by using the same procedure applied to preparation of 6 by using 4 . The product was purified by distillation under full vacuum at $70{ }^{\circ} \mathrm{C}(0.900 \mathrm{~g}, 79 \%)$. The ${ }^{1} \mathrm{H}-\mathrm{NMR}$ spectrum indicated a mixture of two diastereomers in ca. 1:1 ratio. ${ }^{1} \mathrm{H}-\mathrm{NMR}\left(\mathrm{C}_{6} \mathrm{D}_{6}\right): \delta 5.84-5.78(\mathrm{~m}, 1 \mathrm{H},=\mathrm{CH}), 5.48-5.43$ $(\mathrm{m}, 1 \mathrm{H}, \mathrm{CH}=), 3.79-3.69(\mathrm{~m}, 1 \mathrm{H}, \mathrm{NCH}), 2.98$ and $2.89\left(\mathrm{~b}, 1 \mathrm{H}, \mathrm{C}_{5} \mathrm{H}\right), 1.98\left(\mathrm{~s}, 3 \mathrm{H}, \mathrm{CH}_{3}\right), 1.93$ and $1.91(\mathrm{~s}$, $\left.3 \mathrm{H}, \mathrm{CH}_{3}\right), 1.86$ and $1.85\left(\mathrm{~s}, 3 \mathrm{H}, \mathrm{CH}_{3}\right), 1.84$ and $1.82\left(\mathrm{~s}, 3 \mathrm{H}, \mathrm{CH}_{3}\right), 1.51$ and $1.37(\mathrm{dm}, J=17.0 \mathrm{~Hz}, 1 \mathrm{H}$, $\left.\mathrm{SiCH}_{2}\right), 1.25$ and $1.16\left(\mathrm{dm}, J=17.0 \mathrm{~Hz}, 1 \mathrm{H}, \mathrm{SiCH}_{2}\right), 1.07$ and $1.05\left(\mathrm{~d}, J=6.8 \mathrm{~Hz}, 3 \mathrm{H}, \mathrm{NCCH}_{3}\right), 0.57$ and $0.53(\mathrm{~b}, 1 \mathrm{H}, \mathrm{NH}),-0.16$ and $-0.17\left(\mathrm{~s}, 3 \mathrm{H}, \mathrm{SiCH}_{3}\right) \mathrm{ppm} .{ }^{13} \mathrm{C}\left\{{ }^{1} \mathrm{H}\right\}-\mathrm{NMR}\left(\mathrm{C}_{6} \mathrm{D}_{6}\right): \delta 135.57,135.44$, $135.37,133.91$ and $133.85,132.19,122.88$ and $122.87,56.74$ and 56.51, 48.41 and $48.19,27.41$ and 27.36, $14.81,14.69,14.52,12.06,11.69,11.51,-3.91$ and $-4.25 \mathrm{ppm}$. HRMS (EI): $\mathrm{m} / z$ calcd ([M] $\left.{ }^{+} \mathrm{C}_{15} \mathrm{H}_{25} \mathrm{NSi}\right)$ 247.1756. Found: 247.1755.

\subsection{Compound 8}

It was prepared by the same procedure as that used for 6 by using 5 . The product was purified by distillation under full vacuum at $80{ }^{\circ} \mathrm{C}(0.903 \mathrm{~g}, 70 \%) .{ }^{1} \mathrm{H}-\mathrm{NMR}\left(\mathrm{C}_{6} \mathrm{D}_{6}\right): \delta 5.74(\mathrm{dt}, J=10.4,5.2 \mathrm{~Hz}$, $1 \mathrm{H}, \mathrm{CH}=), 5.45(\mathrm{ddd}, J=10.4,3.6,1.6 \mathrm{~Hz}, 1 \mathrm{H},=\mathrm{CH}), 2.93\left(\mathrm{~b}, 1 \mathrm{H}, \mathrm{C}_{5} \mathrm{H}\right), 2.02\left(\mathrm{~s}, 3 \mathrm{H}, \mathrm{CH}_{3}\right), 1.93(\mathrm{~s}, 3 \mathrm{H}$, $\left.\mathrm{CH}_{3}\right), 1.86\left(\mathrm{~s}, 3 \mathrm{H}, \mathrm{CH}_{3}\right), 1.84\left(\mathrm{~s}, 3 \mathrm{H}, \mathrm{CH}_{3}\right), 1.48\left(\mathrm{ddd}, J=16.8,5.2,1.6 \mathrm{~Hz}, 1 \mathrm{H}, \mathrm{SiCH}_{2}\right), 1.20-1.15(1 \mathrm{H}$, $\left.\mathrm{SiCH}_{2}\right), 1.20\left(\mathrm{~s}, 3 \mathrm{H}, \mathrm{NC}\left(\mathrm{CH}_{3}\right)_{2}\right), 1.15\left(\mathrm{~s}, 3 \mathrm{H}, \mathrm{NC}\left(\mathrm{CH}_{3}\right)_{2}\right), 0.55$ (b, $\left.1 \mathrm{H}, \mathrm{NH}\right),-0.17\left(\mathrm{~s}, 3 \mathrm{H}, \mathrm{SiCH}_{3}\right)$ ppm. ${ }^{13} \mathrm{C}\left\{{ }^{1} \mathrm{H}\right\}-\mathrm{NMR}\left(\mathrm{C}_{6} \mathrm{D}_{6}\right): \delta 138.10,135.60,135.52,132.16,131.96,121.34,56.78,52.26,34.99,34.79,14.88$, 14.73, 11.54, 11.51, -3.46 ppm. HRMS (EI): $\mathrm{m} / z$ calcd ([M] ${ }^{+} \mathrm{C}_{16} \mathrm{H}_{27} \mathrm{NSi}$ ) 261.1913. Found: 261.1914.

\subsection{Compound 9}

A bomb reactor was charged with $6(0.500 \mathrm{~g}, 2.14 \mathrm{mmol})$ dissolved in THF $(15 \mathrm{~mL})$ and Pd/C $(10 \mathrm{wt} \%, 0.20 \mathrm{~g}) ; \mathrm{H}_{2}$ gas was introduced to a pressure of 10 bar. After stirring for $5 \mathrm{~h}$, the remaining $\mathrm{H}_{2}$ gas was vented off. $\mathrm{Pd} / \mathrm{C}$ was removed by filtration over Celite. Solvent in the filtrate was removed under vacuum and the resulting crude oil was pure based on ${ }^{1} \mathrm{H}$ - and ${ }^{13} \mathrm{C}-\mathrm{NMR}$ analyses $(0.502 \mathrm{~g}, 99 \%)$. ${ }^{1} \mathrm{H}-\mathrm{NMR}\left(\mathrm{C}_{6} \mathrm{D}_{6}\right): \delta 3.00\left(\mathrm{~b}, 1 \mathrm{H}, \mathrm{C}_{5} \mathrm{H}\right), 2.98-2.91\left(\mathrm{~m}, 1 \mathrm{H}, \mathrm{NCH}_{2}\right), 2.89-2.84\left(\mathrm{~m}, 1 \mathrm{H}, \mathrm{NCH}_{2}\right), 1.96(\mathrm{~s}, 6 \mathrm{H}$, $\left.\mathrm{CH}_{3}\right), 1.86\left(\mathrm{~s}, 3 \mathrm{H}, \mathrm{CH}_{3}\right), 1.84\left(\mathrm{~s}, 3 \mathrm{H}, \mathrm{CH}_{3}\right), 1.75-1.70\left(\mathrm{~m}, 2 \mathrm{H}, \mathrm{CH}_{2}\right), 1.49-1.43\left(\mathrm{~m}, 2 \mathrm{H}, \mathrm{CH}_{2}\right), 0.85-0.78$ $\left.\left(\mathrm{m}, 1 \mathrm{H}, \mathrm{SiCH}_{2}\right), 0.64-0.57\left(\mathrm{~m}, 1 \mathrm{H}, \mathrm{SiCH}_{2}\right), 0.53(\mathrm{~b}, 1 \mathrm{H}, \mathrm{NH}),-0.21\left(\mathrm{~s}, 3 \mathrm{H}, \mathrm{SiCH}_{3}\right) \mathrm{ppm} .{ }^{13} \mathrm{C}^{1} \mathrm{H}\right\}-\mathrm{NMR}$ $\left(\mathrm{C}_{6} \mathrm{D}_{6}\right): \delta 135.42,135.34,132.25,55.73,43.82,31.04,23.77,14.56,14.49,13.01,11.49,-5.23$ ppm. HRMS (EI): $m / z$ calcd $\left([\mathrm{M}]^{+} \mathrm{C}_{14} \mathrm{H}_{25} \mathrm{NSi}\right)$ 235.1756. Found: 235.1758 .

\subsection{Compound $\mathbf{1 0}$}

It was prepared by employing same procedure used for 3 by using dichloromethylvinylsilane instead of allyl(dichloro)methylsilane. The intermediate compound $\left(\mathrm{CH}_{2}=\mathrm{CH}\right)(\mathrm{Me}) \mathrm{Si}\left(\mathrm{C}_{5} \mathrm{Me}_{4}\right) \mathrm{Cl}$ was purified by distillation under full vacuum at $50{ }^{\circ} \mathrm{C}(1.47 \mathrm{~g}, 83 \%) .{ }^{1} \mathrm{H}-\mathrm{NMR}\left(\mathrm{C}_{6} \mathrm{D}_{6}\right): \delta 5.95(\mathrm{dd}, J=19.4$, $14.4 \mathrm{~Hz}, 1 \mathrm{H}, \mathrm{CH}=),\left(\mathrm{dd}, J=14.4,4.0 \mathrm{~Hz}, 1 \mathrm{H},=\mathrm{CH}_{2}\right),\left(\mathrm{dd}, J=19.4,4.0 \mathrm{~Hz}, 1 \mathrm{H},=\mathrm{CH}_{2}\right), 2.97(\mathrm{~b}, 1 \mathrm{H}, \mathrm{C} 5 \mathrm{H})$, $1.98\left(\mathrm{~s}, 3 \mathrm{H}, \mathrm{CH}_{3}\right), 1.92\left(\mathrm{~s}, 3 \mathrm{H}, \mathrm{CH}_{3}\right), 1.73\left(\mathrm{~s}, 6 \mathrm{H}, \mathrm{CH}_{3}\right), 0.17\left(\mathrm{~s}, 3 \mathrm{H}, \mathrm{SiCH}_{3}\right) \mathrm{ppm} .{ }^{13} \mathrm{C}\left\{{ }^{1} \mathrm{H}\right\}-\mathrm{NMR}\left(\mathrm{C}_{6} \mathrm{D}_{6}\right)$ : $\delta 137.89,134.56,134.16,131.38,130.87,55.93,14.73,14.59,11.46,-2.09$ ppm. HRMS (EI): $\mathrm{m} / z$ calcd $\left([\mathrm{M}]^{+}\right.$ $\mathrm{C}_{12} \mathrm{H}_{19} \mathrm{ClSi}$ ) 226.0942. Found: 226.0945. Compound 10 was purified by distillation under full vacuum at $60{ }^{\circ} \mathrm{C}(1.16 \mathrm{~g}, 73 \%) .{ }^{1} \mathrm{H}-\mathrm{NMR}\left(\mathrm{C}_{6} \mathrm{D}_{6}\right): \delta 6.10(\mathrm{dd}, J=20.4,14.6 \mathrm{~Hz}, 1 \mathrm{H}, \mathrm{CH}=), 5.94(\mathrm{dd}, J=14.6,4.2$ $\left.\mathrm{Hz}, 1 \mathrm{H},=\mathrm{CH}_{2}\right), 5.86-5.78(\mathrm{~m}, 1 \mathrm{H}, \mathrm{CH}=), 5.74\left(\mathrm{dd}, J=20.4,4.2 \mathrm{~Hz}, 1 \mathrm{H},=\mathrm{CH}_{2}\right), 5.13(\mathrm{ddd}, J=17.2,3.6$, $\left.2.0 \mathrm{~Hz}, 1 \mathrm{H},=\mathrm{CH}_{2}\right), 4.96\left(\mathrm{ddd}, J=10.0,3.6,2.0 \mathrm{~Hz}, 1 \mathrm{H},=\mathrm{CH}_{2}\right), 3.27-3.21\left(\mathrm{~m}, 2 \mathrm{H}, \mathrm{NCH}_{2}\right), 2.86(\mathrm{~b}, 1 \mathrm{H}$, $\left.\mathrm{C}_{5} \mathrm{H}\right), 2.00\left(\mathrm{~s}, 3 \mathrm{H}, \mathrm{CH}_{3}\right), 1.98\left(\mathrm{~s}, 3 \mathrm{H}, \mathrm{CH}_{3}\right), 1.84\left(\mathrm{~s}, 6 \mathrm{H}, \mathrm{CH}_{3}\right), 0.32(\mathrm{~b}, 1 \mathrm{H}, \mathrm{NH}), 0.03\left(\mathrm{~s}, 3 \mathrm{H}, \mathrm{SiCH}_{3}\right) \mathrm{ppm}$. ${ }^{13} \mathrm{C}\left\{{ }^{1} \mathrm{H}\right\}-\mathrm{NMR}\left(\mathrm{C}_{6} \mathrm{D}_{6}\right): \delta 140.66,138.11,135.68,132.05,112.80,55.48,44.97,14.92,11.56,-4.61 \mathrm{ppm}$. HRMS (EI): $m / z$ calcd. ([M] $\left.{ }^{+} \mathrm{C}_{15} \mathrm{H}_{25} \mathrm{NSi}\right)$ 247.1756. Found: 247.1755 . 


\subsection{Compound $\mathbf{1 1}$}

It was prepared by employing the same procedure as that used for 6 by using 10 . The product was purified through distillation under full vacuum at $50{ }^{\circ} \mathrm{C}(1.56 \mathrm{~g}, 96 \%)$. ${ }^{1} \mathrm{H}-\mathrm{NMR}\left(\mathrm{C}_{6} \mathrm{D}_{6}\right): \delta 6.77$ $(\mathrm{ddd}, J=10.0,3.6,1.6 \mathrm{~Hz}, 1 \mathrm{H},=\mathrm{CH}), 6.11(\mathrm{dd}, J=10.0,2.0 \mathrm{~Hz}, 1 \mathrm{H},=\mathrm{CH}), 3.71-3.62\left(\mathrm{~m}, 2 \mathrm{H}, \mathrm{NCH}_{2}\right), 3.05$ (b, 1H, $\left.\mathrm{C}_{5} \mathrm{H}\right), 1.99$ (s, 3H, $\left.\mathrm{CH}_{3}\right), 1.96\left(\mathrm{~s}, 3 \mathrm{H}, \mathrm{CH}_{3}\right), 1.85\left(\mathrm{~s}, 3 \mathrm{H}, \mathrm{CH}_{3}\right), 1.83\left(\mathrm{~s}, 3 \mathrm{H}, \mathrm{CH}_{3}\right), 0.73(\mathrm{~b}, 1 \mathrm{H}, \mathrm{NH})$, $-0.16\left(\mathrm{~s}, 3 \mathrm{H}, \mathrm{SiCH}_{3}\right)$ ppm. ${ }^{13} \mathrm{C}\left\{{ }^{1} \mathrm{H}\right\}-\mathrm{NMR}\left(\mathrm{C}_{6} \mathrm{D}_{6}\right): \delta 149.15,135.79,131.23,126.55,59.59,52.28,14.08$, 14.05, 11.48, 11.44, -5.01 ppm. HRMS (EI): $m / z$ calcd ([M] $\left.{ }^{+} \mathrm{C}_{13} \mathrm{H}_{21} \mathrm{NSi}\right)$ 219.1443. Found: 219.1441.

\subsection{Compound 12}

It was prepared by employing the same procedure as that used for 9 by using $11(1.53 \mathrm{~g}, 97 \%)$. ${ }^{1} \mathrm{H}-\mathrm{NMR}\left(\mathrm{C}_{6} \mathrm{D}_{6}\right): \delta 2.94-2.87\left(\mathrm{~m}, 2 \mathrm{H}, \mathrm{NCH}_{2}\right), 1.96\left(\mathrm{~s}, 3 \mathrm{H}, \mathrm{CH}_{3}\right), 1.94\left(\mathrm{~s}, 3 \mathrm{H}, \mathrm{CH}_{3}\right), 1.86\left(\mathrm{~s}, 3 \mathrm{H}, \mathrm{CH}_{3}\right)$, $1.84\left(\mathrm{~s}, 3 \mathrm{H}, \mathrm{CH}_{3}\right), 1.81-1.53\left(\mathrm{~m}, 2 \mathrm{H}, \mathrm{CH}_{2}\right), 0.96-0.60\left(\mathrm{~m}, 2 \mathrm{H}, \mathrm{CH}_{2}\right), 0.66(\mathrm{~b}, 1 \mathrm{H}, \mathrm{NH}),-0.23\left(\mathrm{~s}, 3 \mathrm{H}, \mathrm{SiCH}_{3}\right)$ ppm. ${ }^{13} \mathrm{C}\left\{{ }^{1} \mathrm{H}\right\}-\mathrm{NMR}\left(\mathrm{C}_{6} \mathrm{D}_{6}\right): \delta 135.56,135.45,131.95,67.73,57.33,45.54,25.77,14.15,14.07,11.60,11.46$, $-5.22 \mathrm{ppm}$.

\subsection{Compound 13}

Compound 6 ( $0.500 \mathrm{~g}, 2.14 \mathrm{mmol})$ dissolved in THF $(40 \mathrm{~mL})$ was added to a solution of $\mathrm{MeMgCl}$ in THF (3.0 M, $2.88 \mathrm{~mL}, 8.65 \mathrm{mmol})$. The resulting solution was stirred for three days. During the course of the reaction, methane gas evolved and was vented through a bubbler. $\mathrm{TiCl}_{4}(\mathrm{DME})(0.600 \mathrm{~g}$, $2.14 \mathrm{mmol}$ ) was added at $-30^{\circ} \mathrm{C}$ and the resulting solution was stirred at room temperature for $3 \mathrm{~h}$. All volatiles were removed under vacuum, and hexane $(10 \mathrm{~mL})$ was added. The insoluble fraction was removed by filtration with the aid of Celite. Solvent in the filtrate was removed under vacuum. The resulting dark brown oil was redissolved in hexane $(5 \mathrm{~mL})$ and filtration was performed another time. A dark brown oil was obtained by removal of the solvent from the filtrate, which was pure based on ${ }^{1} \mathrm{H}$ - and ${ }^{13} \mathrm{C}-\mathrm{NMR}$ analyses $(0.437 \mathrm{~g}, 63 \%)$. ${ }^{1} \mathrm{H}-\mathrm{NMR}\left(\mathrm{C}_{6} \mathrm{D}_{6}\right)$ : 5.77-5.70 (m, 1H, =CH), 5.57-5.52 (m, $1 \mathrm{H},=\mathrm{CH}), 5.47\left(\mathrm{ddd}, J=19.5,6.0,3.2 \mathrm{~Hz}, 1 \mathrm{H}, \mathrm{NCH}_{2}\right), 4.63\left(\mathrm{dm}, J=19.5 \mathrm{~Hz}, 1 \mathrm{H}, \mathrm{NCH}_{2}\right), 1.98(\mathrm{~s}, 3 \mathrm{H}$, $\left.\mathrm{CH}_{3}\right), 1.96\left(\mathrm{~s}, 3 \mathrm{H}, \mathrm{CH}_{3}\right), 1.94\left(\mathrm{~s}, 3 \mathrm{H}, \mathrm{CH}_{3}\right), 1.87\left(\mathrm{~s}, 3 \mathrm{H}, \mathrm{CH}_{3}\right), 1.73\left(\mathrm{dt}, J=17.2,8.0 \mathrm{~Hz}, 1 \mathrm{H}, \mathrm{SiCH}_{2}\right), 1.18$ (ddt, $\left.J=17.2,6.8,1.2 \mathrm{~Hz}, 1 \mathrm{H}, \mathrm{SiCH}_{2}\right), 0.59$ (s, 3H, SiCH $), 0.46\left(\mathrm{~s}, 3 \mathrm{H}, \mathrm{TiCH}_{3}\right), 0.43\left(\mathrm{~s}, 3 \mathrm{H}, \mathrm{TiCH}_{3}\right) \mathrm{ppm}$. ${ }^{13} \mathrm{C}\left\{{ }^{1} \mathrm{H}\right\}-\mathrm{NMR}\left(\mathrm{C}_{6} \mathrm{D}_{6}\right): \delta 134.67,133.29,130.26,128.56,127.26,122.87,95.54,53.75,52.11,49.06,15.24$, $14.94,14.02,11.99,11.89,2.84 \mathrm{ppm}$.

\subsection{Compound 14}

It was prepared by employing the same procedure used for $\mathbf{1 3}$ by using $\mathbf{9}$. A dark brown oil was obtained by removal of the solvent from the filtrate, which was pure based on ${ }^{1} \mathrm{H}-$ and ${ }^{13} \mathrm{C}-\mathrm{NMR}$ analyses $(0.403 \mathrm{~g}, 58 \%) .{ }^{1} \mathrm{H}-\mathrm{NMR}\left(\mathrm{C}_{6} \mathrm{D}_{6}\right): \delta 5.20-5.14\left(\mathrm{~m}, 1 \mathrm{H}, \mathrm{NCH}_{2}\right), 3.68-3.61\left(\mathrm{~m}, 1 \mathrm{H}, \mathrm{NCH}_{2}\right), 2.01$ $\left(\mathrm{s}, 3 \mathrm{H}, \mathrm{CH}_{3}\right), 1.99\left(\mathrm{~s}, 6 \mathrm{H}, \mathrm{CH}_{3}\right), 1.94-1.88\left(\mathrm{~m}, 1 \mathrm{H}, \mathrm{CH}_{2}\right), 1.87\left(\mathrm{~s}, 3 \mathrm{H}, \mathrm{CH}_{3}\right), 1.49-1.44\left(\mathrm{~m}, 1 \mathrm{H}, \mathrm{CH}_{2}\right)$, 1.41-1.29 (m, 2H, $\left.\mathrm{CH}_{2}\right), 0.94\left(\mathrm{td}, J=14.0,5.6 \mathrm{~Hz}, 1 \mathrm{H}, \mathrm{CH}_{2}\right), 0.68-0.62\left(\mathrm{dm}, J=14.0 \mathrm{~Hz}, 1 \mathrm{H}, \mathrm{CH}_{2}\right), 0.57$ $\left.\left(\mathrm{s}, 3 \mathrm{H}, \mathrm{SiCH}_{3}\right), 0.47\left(\mathrm{~s}, 3 \mathrm{H}, \mathrm{TiCH}_{3}\right), 0.41\left(\mathrm{~s}, 3 \mathrm{H}, \mathrm{TiCH}_{3}\right) \mathrm{ppm} .{ }^{13} \mathrm{C}^{1}{ }^{1} \mathrm{H}\right\}-\mathrm{NMR}\left(\mathrm{C}_{6} \mathrm{D}_{6}\right): \delta 134.70,132.92$, $128.19,127.02,95.87,53.44,51.48,48.41,31.75,23.09,15.81,15.22,14.86,12.02,11.91,0.82$ ppm. Anal. Calcd. for $\mathrm{C}_{16} \mathrm{H}_{29} \mathrm{NSiTi}(311.36 \mathrm{~g} / \mathrm{mol})$ : C 61.72, H 9.39, N 4.50\%. Found: C 61.69, H 9.06, N 4.94\%.

\subsection{Compound 15}

$n$ BuLi $(8.8 \mathrm{mmol})$ was added to $7(1.16 \mathrm{~g}, 4.4 \mathrm{mmol})$ dissolved in diethyl ether $(15 \mathrm{~mL})$ at $-30{ }^{\circ} \mathrm{C}$ and the resulting solution was stirred for $3 \mathrm{~h}$ at $-30^{\circ} \mathrm{C}$. The dilithiated compound precipitated as a white solid, which was isolated by decantation and dried under vacuum $(1.18 \mathrm{~g}, 98 \%)$. The isolated solids were dissolved in THF (30 mL), and $\mathrm{MeMgCl}$ in THF (3.0 M, $2.87 \mathrm{~mL}, 8.6 \mathrm{mmol})$ and $\mathrm{TiCl}_{4}(\mathrm{DME})$ $(1.21 \mathrm{~g}, 4.3 \mathrm{mmol})$ were successively added at $-30^{\circ} \mathrm{C}$. After stirring for $3 \mathrm{~h}$, the product was isolated by using the same procedure employed for $13(0.713 \mathrm{~g}, 49 \%)$. The ${ }^{1} \mathrm{H}-\mathrm{NMR}$ spectrum indicated a mixture of two diastereomers in ca. 1:1 ratio. ${ }^{1} \mathrm{H}-\mathrm{NMR}\left(\mathrm{C}_{6} \mathrm{D}_{6}\right): \delta 5.72-5.44(\mathrm{~m}, 2 \mathrm{H}, \mathrm{CH}=), 5.58$ and $4.45(\mathrm{~m}, 1 \mathrm{H}$, 
$\mathrm{NCH}), 2.08$ and $1.43\left(\mathrm{~d}, J=7.2 \mathrm{~Hz}, 3 \mathrm{H}, \mathrm{NCCH}_{3}\right), 1.99$ and $1.98\left(\mathrm{~s}, 3 \mathrm{H}, \mathrm{CH}_{3}\right), 1.97$ and $1.96\left(\mathrm{~s}, 3 \mathrm{H}, \mathrm{CH}_{3}\right)$, 1.93 and $1.87\left(\mathrm{~s}, 3 \mathrm{H}, \mathrm{CH}_{3}\right), 1.90\left(\mathrm{~s}, 3 \mathrm{H}, \mathrm{CH}_{3}\right), 1.66\left(\mathrm{dm}, J=17.2,3.6 \mathrm{~Hz}, 1 \mathrm{H}, \mathrm{SiCH}_{2}\right), 1.14$ and 1.09 (dd, $\left.J=17.2,6.8 \mathrm{~Hz}, 1 \mathrm{H}, \mathrm{SiCH}_{2}\right), 0.58$ and $0.54\left(\mathrm{~s}, 3 \mathrm{H}, \mathrm{SiCH}_{3}\right), 0.46$ and $0.45\left(\mathrm{~s}, 3 \mathrm{H}, \mathrm{TiCH}_{3}\right), 0.43$ and 0.41 $\left(\mathrm{s}, 3 \mathrm{H}, \mathrm{TiCH}_{3}\right)$ ppm. ${ }^{13} \mathrm{C}\left\{{ }^{1} \mathrm{H}\right\}-\mathrm{NMR}\left(\mathrm{C}_{6} \mathrm{D}_{6}\right): \delta 136.35$ and $135.72,134.59,133.60,133.53,133.29,128.87$, $128.75,128.52,127.23,122.41$ and $121.94,96.05$ and $95.45,57.79$ and 57.20, 53.66 and 52.96, 50.18 and $48.85,27.04$ and $26.54,15.28,15.11,14.97,14.13,13.56,12.02,11.97,11.95,4.46$ and 1.41 ppm.

\subsection{Compound 16}

It was prepared by using the same procedure as that employed for $\mathbf{1 5}$ by using $\mathbf{3}$. A dark brown oil was obtained by removal of the solvent from the filtrate, which was pure based on ${ }^{1} \mathrm{H}$ - and ${ }^{13} \mathrm{C}-\mathrm{NMR}$ analyses $(1.27 \mathrm{~g}, 84 \%)$. ${ }^{1} \mathrm{H}-\mathrm{NMR}\left(\mathrm{C}_{6} \mathrm{D}_{6}\right): 6.02-5.81(\mathrm{~m}, 2 \mathrm{H}, \mathrm{CH}=), 5.16-4.92\left(\mathrm{~m}, 4 \mathrm{H},=\mathrm{CH}_{2}\right), 4.42(\mathrm{ddt}$, $\left.J=15.6,6.4,1.6 \mathrm{~Hz}, 1 \mathrm{H}, \mathrm{NCH}_{2}\right), 4.26\left(\mathrm{ddt}, J=15.6,6.4,1.6 \mathrm{~Hz}, 1 \mathrm{H}, \mathrm{NCH}_{2}\right), 1.96\left(\mathrm{~s}, 6 \mathrm{H}, \mathrm{CH}_{3}\right), 1.89(\mathrm{~s}, 3 \mathrm{H}$, $\left.\mathrm{CH}_{3}\right), 1.85\left(\mathrm{~s}, 3 \mathrm{H}, \mathrm{CH}_{3}\right), 0.51\left(\mathrm{~s}, 3 \mathrm{H}, \mathrm{TiCH}_{3}\right), 0.49\left(\mathrm{~s}, 3 \mathrm{H}, \mathrm{TiCH}_{3}\right), 0.41\left(\mathrm{~s}, 3 \mathrm{H}, \mathrm{SiCH}_{3}\right)$ ppm. ${ }^{13} \mathrm{C}\left\{{ }^{1} \mathrm{H}\right\}-\mathrm{NMR}$ $\left(\mathrm{C}_{6} \mathrm{D}_{6}\right): \delta 139.40,134.40,134.09,133.73,128.20,114.58,114.27,95.97,53.78,51.39,27.40,15.21,15.12$, 12.01, 0.48 ppm.

\subsection{Compound $\mathbf{1 7}$}

It was prepared by using the same procedure as employed for $\mathbf{1 5}$ by using 10. A dark brown oil was obtained by removal of the solvent from the filtrate, which was pure based on ${ }^{1} \mathrm{H}$ - and ${ }^{13} \mathrm{C}-\mathrm{NMR}$ analyses $(1.39 \mathrm{~g}, 88 \%) .{ }^{1} \mathrm{H}-\mathrm{NMR}\left(\mathrm{C}_{6} \mathrm{D}_{6}\right): \delta 6.23(\mathrm{dd}, J=20.0,14.4 \mathrm{~Hz}, 1 \mathrm{H}, \mathrm{CH}=), 6.01-5.96(\mathrm{~m}, 1 \mathrm{H}, \mathrm{CH}=)$, $5.92\left(\mathrm{dd}, J=14.4,3.6 \mathrm{~Hz}, 1 \mathrm{H},=\mathrm{CH}_{2}\right), 5.72\left(\mathrm{dd}, J=20.0,3.6 \mathrm{~Hz}, 1 \mathrm{H},=\mathrm{CH}_{2}\right), 5.16(\mathrm{dm}, J=16.8 \mathrm{~Hz}, 1 \mathrm{H}$, $\left.=\mathrm{CH}_{2}\right), 5.02\left(\mathrm{dm}, J=9.2 \mathrm{~Hz}, 1 \mathrm{H},=\mathrm{CH}_{2}\right), 4.86\left(\mathrm{ddt}, J=15.2,6.0,1.6 \mathrm{~Hz}, 1 \mathrm{H}, \mathrm{NCH}_{2}\right), 4.59(\mathrm{ddt}, J=15.2$, 6.0, $\left.1.6 \mathrm{~Hz}, 1 \mathrm{H}, \mathrm{NCH}_{2}\right), 1.98\left(\mathrm{~s}, 3 \mathrm{H}, \mathrm{CH}_{3}\right), 1.97\left(\mathrm{~s}, 3 \mathrm{H}, \mathrm{CH}_{3}\right), 1.96\left(\mathrm{~s}, 3 \mathrm{H}, \mathrm{CH}_{3}\right), 1.90\left(\mathrm{~s}, 3 \mathrm{H}, \mathrm{CH}_{3}\right), 0.55$ $\left.\left(\mathrm{s}, 3 \mathrm{H}, \mathrm{TiCH}_{3}\right), 0.53\left(\mathrm{~s}, 3 \mathrm{H}, \mathrm{TiCH}_{3}\right), 0.46\left(\mathrm{~s}, 3 \mathrm{H}, \mathrm{SiCH}_{3}\right) \mathrm{ppm} .{ }^{13} \mathrm{C}^{1}{ }^{1} \mathrm{H}\right\}-\mathrm{NMR}\left(\mathrm{C}_{6} \mathrm{D}_{6}\right): \delta 139.68,139.38$, $134.53,134.17,133.43,114.31,96.05,53.84,51.69,51.49,15.62,15.24,12.03,1.05$ ppm.

\subsection{Compound 18}

It was prepared by using the same procedure as employed for 9 by using 17. A dark brown oil was obtained by removal of the solvent from the filtrate, which was pure based on ${ }^{1} \mathrm{H}$ - and ${ }^{13} \mathrm{C}-\mathrm{NMR}$ analyses (1.26 g, 98\%). ${ }^{1} \mathrm{H}-\mathrm{NMR}\left(\mathrm{C}_{6} \mathrm{D}_{6}\right): \delta 4.23-4.10\left(\mathrm{~m}, 2 \mathrm{H}, \mathrm{NCH}_{2}\right), 2.00\left(\mathrm{~s}, 3 \mathrm{H}, \mathrm{CH}_{3}\right), 1.99(\mathrm{~s}, 3 \mathrm{H}$, $\left.\mathrm{CH}_{3}\right), 1.89\left(\mathrm{~s}, 3 \mathrm{H}, \mathrm{CH}_{3}\right), 1.88\left(\mathrm{~s}, 3 \mathrm{H}, \mathrm{CH}_{3}\right), 1.66$ (q, J = 7.4 Hz, 2H, SiCH$), 1.37\left(\mathrm{~b}, 2 \mathrm{H}, \mathrm{CH}_{2}\right), 1.09$ (t, $\left.J=7.4 \mathrm{~Hz}, 3 \mathrm{H}, \mathrm{CH}_{3}\right), 0.99\left(\mathrm{t}, J=7.4 \mathrm{~Hz}, 3 \mathrm{H}, \mathrm{CH}_{3}\right), 0.49\left(\mathrm{~s}, 3 \mathrm{H}, \mathrm{TiCH}_{3}\right), 0.48\left(\mathrm{~s}, 3 \mathrm{H}, \mathrm{TiCH}_{3}\right), 0.37(\mathrm{~s}, 3 \mathrm{H}$, $\left.\mathrm{SiCH}_{3}\right)$ ppm. ${ }^{13} \mathrm{C}\left\{{ }^{1} \mathrm{H}\right\}-\mathrm{NMR}\left(\mathrm{C}_{6} \mathrm{D}_{6}\right): \delta 134.29,133.87,95.66,53.41,49.87,28.48,15.25,14.79,12.38,12.03$, $11.23,6.97,0.42 \mathrm{ppm}$.

\subsection{Ethylene/1-Octene Copolymerization}

Methylcyclohexane $(25 \mathrm{~mL})$ containing 1-octene $(3.0 \mathrm{~g})$ was introduced into a bomb reactor in a glove box. The reactor was assembled, removed out from the glove box, and heated to $130{ }^{\circ} \mathrm{C}$ using an oil bath. An activated catalyst was prepared by mixing the complex $(0.5 \mu \mathrm{mol}), \mathrm{iBu}_{3} \mathrm{Al}\left(\right.$ or $\left.\left[\mathrm{iBu}_{2} \mathrm{Al}\right]_{2} \mathrm{O}\right)$ $(0.20 \mathrm{mmol}-\mathrm{Al})$, and $\left[\mathrm{Ph}_{3} \mathrm{C}\right]\left[\mathrm{B}\left(\mathrm{C}_{6} \mathrm{~F}_{5}\right)_{4}\right](2.0 \mu \mathrm{mol})$ for $2 \mathrm{~min}$. After adding the activated catalyst using a syringe, the system was immediately charged with ethylene gas (30 bar). The temperature increased rapidly due to the exothermic reaction, and the temperature profile is summarized in Table 1. The polymerization was conducted for 3 min using a continuous feed of ethylene at 30 bar and the reaction was quenched by venting the ethylene gas and introducing methanol through a syringe. After adding methanol $(10 \mathrm{~mL})$, the sticky polymer lump that was deposited was washed with methanol $(10 \mathrm{~mL})$ three times. The polymer was dried in a vacuum oven at $80{ }^{\circ} \mathrm{C}$. The ${ }^{1} \mathrm{H}-\mathrm{NMR}$ spectra showed the methyl $\left(\mathrm{CH}_{3}\right)$ signal $(0.93-1.02 \mathrm{ppm})$ that was well isolated from the methine $(\mathrm{CH})$ and methylene $\left(\mathrm{CH}_{2}\right)$ signals (1.30-1.40 ppm), and the 1-octene content could be calculated by the signal intensities of the two regions. ${ }^{1} \mathrm{H}-\mathrm{NMR}$ spectra of the polymers $(5 \mathrm{mg})$ were obtained at $70{ }^{\circ} \mathrm{C}$ after dissolution in deuterated toluene. It was proved that the 1 -octene contents calculated from the ${ }^{1} \mathrm{H}-\mathrm{NMR}$ and 
${ }^{13} \mathrm{C}-\mathrm{NMR}$ spectra are identical [26]. The polymer chain of the lowest molecular weight generated with CGC $\left(M_{n}, 9300\right.$; 1-octene content $\left.21 \mathrm{~mol} \%\right)$ is comprised of 41 1-octene units and 165 ethylene units, and the contribution of $-\mathrm{CH}_{3}$ end group to the intensity of the $\mathrm{CH}_{3}$ signal in the ${ }^{1} \mathrm{H}-\mathrm{NMR}$ spectrum is negligible.

\section{Conclusions}

RCM was successfully performed on ligand frameworks of CGC bearing allyl-Si (or vinyl-Si) and allyl-N units $\left(\mathrm{Me}_{4} \mathrm{C}_{5} \mathrm{H}-\mathrm{Si}(\mathrm{Me})\left(\left(\mathrm{CH}_{2}\right)_{\mathrm{a}} \mathrm{CH}=\mathrm{CH}_{2}\right)-\mathrm{NH}\left(\mathrm{C}(\mathrm{R})\left(\mathrm{R}^{\prime}\right) \mathrm{CH}=\mathrm{CH}_{2}\right)\right.$, where $\mathrm{R} \mathrm{R}^{\prime}=\mathrm{H}$ or $\mathrm{Me} ; \mathrm{a}=0$ or 1$)$ to form six- or five-membered ring frameworks, $-\mathrm{Si}\left(\mathrm{Me}_{4} \mathrm{C}_{5} \mathrm{H}\right)(\mathrm{Me})\left[\mathrm{CH}_{2}\right]_{\mathrm{a}} \mathrm{CH}=$ $\mathrm{CHC}(\mathrm{R})\left(\mathrm{R}^{\prime}\right) \mathrm{NH}-$, by employing Schrock's Mo-catalyst. Using the precursors and products of $\mathrm{RCM}, \mathrm{CGC}$ derivatives $\left[-\mathrm{Si}\left(\eta^{5}-\mathrm{Me}_{4} \mathrm{C}_{5}\right)(\mathrm{Me}) \mathrm{CH}_{2} \mathrm{CH}=\mathrm{CHC}(\mathrm{R})(\mathrm{H}) \mathrm{N}-\right] \mathrm{TiMe}_{2}(\mathbf{1 3}, \mathrm{R}=\mathrm{H} ; \mathbf{1 5}, \mathrm{R}=\mathrm{Me})$, $\left[-\mathrm{Si}\left(\eta^{5}-\mathrm{Me}_{4} \mathrm{C}_{5}\right)(\mathrm{Me}) \mathrm{CH}_{2} \mathrm{CH}_{2} \mathrm{CH}_{2} \mathrm{CH}_{2} \mathrm{~N}\right] \mathrm{TiMe}_{2} \quad(\mathbf{1 4}), \quad\left[\left(\eta^{5}-\mathrm{Me}_{4} \mathrm{C}_{5}\right) \mathrm{Si}(\mathrm{Me})\left(\mathrm{CH}_{2} \mathrm{CH}=\mathrm{CH}_{2}\right) \mathrm{NCH}_{2} \mathrm{CH}=\right.$ $\left.\mathrm{CH}_{2}\right] \mathrm{TiMe}_{2}$ (16), $\left[\left(\eta^{5}-\mathrm{Me}_{4} \mathrm{C}_{5}\right) \mathrm{Si}(\mathrm{Me})\left(\mathrm{CH}=\mathrm{CH}_{2}\right) \mathrm{NCH}_{2} \mathrm{CH}=\mathrm{CH}_{2}\right] \mathrm{TiMe}_{2}(\mathbf{1 7})$, and $\left[\left(\eta^{5}-\mathrm{Me}_{4} \mathrm{C}_{5}\right) \mathrm{Si}(\mathrm{Me})\right.$ $\left.\left(\mathrm{CH}_{2} \mathrm{CH}_{3}\right) \mathrm{NCH}_{2} \mathrm{CH}_{2} \mathrm{CH}_{3}\right] \mathrm{TiMe}_{2}$ (18) were successfully prepared. The newly prepared complexes exhibit lower activity than the prototype CGC, $\left[\mathrm{Me}_{2} \mathrm{Si}\left(\eta^{5}-\mathrm{Me}_{4} \mathrm{C}_{5}\right)\left(\mathrm{N}^{t} \mathrm{Bu}\right)\right] \mathrm{TiMe}_{2}$, when activated with $\left[\mathrm{Ph}_{3} \mathrm{C}\right]\left[\mathrm{B}\left(\mathrm{C}_{6} \mathrm{~F}_{5}\right)_{4}\right] / \mathrm{iBu}_{3} \mathrm{Al}$, but the catalytic activity of these species was significantly improved by using $\left[\mathrm{iBu}_{2} \mathrm{Al}\right]_{2} \mathrm{O}$ instead of $\mathrm{iBu}_{3} \mathrm{Al}$. The $14 /\left[\mathrm{Ph}_{3} \mathrm{C}\right]\left[\mathrm{B}\left(\mathrm{C}_{6} \mathrm{~F}_{5}\right)_{4}\right] /\left[\mathrm{iBu}_{2} \mathrm{Al}\right]_{2} \mathrm{O}$ and $18 /\left[\mathrm{Ph}_{3} \mathrm{C}\right]\left[\mathrm{B}\left(\mathrm{C}_{6} \mathrm{~F}_{5}\right)_{4}\right] /$ $\left[\mathrm{iBu}_{2} \mathrm{Al}\right]_{2} \mathrm{O}$ species exhibit high activity, comparable to that of $\mathrm{CGC} /\left[\mathrm{Ph}_{3} \mathrm{C}\right]\left[\mathrm{B}\left(\mathrm{C}_{6} \mathrm{~F}_{5}\right)_{4}\right] / \mathrm{iBu}_{3} \mathrm{Al}(4.7$, 3.5 , and $5.0 \times 10^{6} \mathrm{~g} / \mathrm{mol}-\mathrm{Ti}$, respectively). Advantageously, higher molecular weight polymers were produced with narrow molecular weight distributions by using 14 and $18\left(M_{n}, 36,69\right.$, and $9.3 \mathrm{kDa}$ for 14, 18 and CGC, respectively).

Acknowledgments: This work was supported by the Korea Carbon Capture and Storage (CCS) R\&D Center (KCRC) (Grant No. 2012-0008935) and the Priority Research Centers Program (No. 2012-0006687) funded by the Korean Government (Ministry of Science, ICT and future planning).

Author Contributions: B. Y. Lee conceived and designed the experiments; S. Lee and C. S. Kim synthesized the complexes; S. S. Park and J. G. Kim performed the polymerizations.

Conflicts of Interest: The authors declare no conflict of interest.

\section{References}

1. Kaminsky, W. Discovery of methylaluminoxane as cocatalyst for olefin polymerization. Macromolecules 2012, 45, 3289-3297. [CrossRef]

2. Stürzel, M.; Mihan, S.; Mülhaupt, R. From multisite polymerization catalysis to sustainable materials and all-polyolefin composites. Chem. Rev. 2016, 116, 1398-1433. [CrossRef] [PubMed]

3. Liu, P.; Liu, W.; Wang, W.-J.; Li, B.-G.; Zhu, S. A Comprehensive review on controlled synthesis of long-chain branched polyolefins: Part 1, Single catalyst systems. Macromol. React. Eng. 2016, 10, 156-179. [CrossRef]

4. Tsurugi, H.; Yamamoto, K.; Rochat, R.; Mashima, K. Non-bridged half-metallocene complexes of group 4-6 metals with chelating ligands as well-defined catalysts for $\alpha$-olefin polymerization. Polym. J. 2015, 47, 2-17. [CrossRef]

5. Shiono, T. Living polymerization of olefins with ansa-dimethylsilylene(fluorenyl)(amido)dimethyltitaniumbased catalysts. Polym. J. 2011, 43, 331-351. [CrossRef]

6. Kim, T.-J.; Kim, S.-K.; Kim, B.-J.; Hahn, J.S.; Ok, M.-A.; Song, J.H.; Shin, D.-H.; Ko, J.; Cheong, M.; Kim, J.; et al. Half-metallocene titanium(IV) phenyl phenoxide for high temperature olefin polymerization: Ortho-substituent effect at ancillary o-phenoxy ligand for enhanced catalytic performance. Macromolecules 2009, 42, 6932-6943. [CrossRef]

7. Stephan, D.W. The road to early-transition-metal phosphinimide olefin polymerization catalysts. Organometallics 2005, 24, 2548-2560. [CrossRef]

8. Senda, T.; Hanaoka, H.; Hino, T.; Oda, Y.; Tsurugi, H.; Mashima, K. Substituent effects on silicon of bridged tetramethylcyclopentadienyl-phenoxy titanium complexes for controlling the regiochemistry and molecular weight in 1-olefin polymerization. Macromolecules 2009, 42, 8006-8009. [CrossRef] 
9. Itagaki, K.; Hasumi, S.; Fujiki, M.; Nomura, K. Ethylene polymerization and ethylene/1-octene copolymerization using group 4 half-metallocenes containing aryloxo ligands, $\mathrm{Cp}^{*} \mathrm{MCl}_{2}(\mathrm{OAr})[\mathrm{M}=\mathrm{Ti}$, $\left.\mathrm{Zr}, \mathrm{Hf} ; \mathrm{Ar}=\mathrm{O}-2,6-\mathrm{R}_{2} \mathrm{C}_{6} \mathrm{H}_{3}, \mathrm{R}={ }^{t} \mathrm{Bu}, \mathrm{Ph}\right]-\mathrm{MAO}$ catalyst systems. J. Mol. Catal. A Chem. 2009, 303, 102-109. [CrossRef]

10. Nomura, K. Half-titanocenes containing anionic ancillary donor ligands as promising new catalysts for precise olefin polymerisation. Dalton Trans. 2009, 8811-8823. [CrossRef] [PubMed]

11. Lamberti, M.; Mazzeo, M.; Pappalardo, D.; Pellecchia, C. Mechanism of stereospecific polymerization of $\alpha$-olefins by late-transition metal and octahedral group 4 metal catalysts. Coord. Chem. Rev. 2009, 253, 2082-2097. [CrossRef]

12. Makio, H.; Terao, H.; Iwashita, A.; Fujita, T. FI catalysts for olefin polymerization-A comprehensive treatment. Chem. Rev. 2011, 111, 2363-2449. [CrossRef] [PubMed]

13. Boussie, T.R.; Diamond, G.M.; Goh, C.; Hall, K.A.; LaPointe, A.M.; Leclerc, M.; Lund, C.; Murphy, V.; Shoemaker, J.A.W.; Tracht, U.; et al. A fully integrated high-throughput screening methodology for the discovery of new polyolefin catalysts: Discovery of a new class of high temperature single-site group (IV) copolymerization catalysts. J. Am. Chem. Soc. 2003, 125, 4306-4317. [CrossRef] [PubMed]

14. Jun, S.H.; Park, J.H.; Lee, C.S.; Park, S.Y.; Go, M.J.; Lee, J.; Lee, B.Y. Preparation of phosphine-amido hafnium and zirconium complexes for olefin polymerization. Organometallics 2013, 32, 7357-7365. [CrossRef]

15. Hwang, E.Y.; Park, G.H.; Lee, C.S.; Kang, Y.Y.; Lee, J.; Lee, B.Y. Preparation of octahydro- and tetrahydro-[1,10]phenanthroline zirconium and hafnium complexes for olefin polymerization. Dalton Trans. 2015, 44, 3845-3855. [CrossRef] [PubMed]

16. Pérez, M.A.; Quijada, R.; Ortega-Jiménez, F.; Alvarez-Toledano, C. Cyclopalladated complexes derivates of phenylhydrazones and their use as catalysts in ethylene polymerization. J. Mol. Catal. A Chem. 2005, 226, 291-295. [CrossRef]

17. Delferro, M.; Marks, T.J. Multinuclear olefin polymerization catalysts. Chem. Rev. 2011, 111, $2450-2485$. [CrossRef] [PubMed]

18. Cano, J.; Kunz, K. How to synthesize a constrained geometry catalyst (CGC)-A survey. J. Organomet. Chem. 2007, 692, 4411-4423. [CrossRef]

19. Klosin, J.; Fontaine, P.P.; Figureueroa, R. Development of group IV molecular catalysts for high temperature ethylene- $\alpha$-olefin copolymerization reactions. Acc. Chem. Res. 2015, 48, 2004-2016. [CrossRef] [PubMed]

20. Chai, J.; Abboud, K.A.; Miller, S.A. Sterically expanded CGC catalysts: Substituent effects on ethylene and $\alpha$-olefin polymerization. Dalton Trans. 2013, 42, 9139-9147. [CrossRef] [PubMed]

21. Wu, C.J.; Nayab, S.; Woo, H.Y.; Hahn, J.S.; Lee, H.S.; Kang, S.O.; Lee, H. Synthesis and X-ray crystal structure of $\left[\mathrm{Me}_{2} \mathrm{Si}\left(\mathrm{C}_{5} \mathrm{Me}_{2} \mathrm{H}_{2}\right)\left({ }^{t} \mathrm{BuN}\right)\right] \mathrm{MCl}_{2}(\mathrm{M}=\mathrm{Ti}, \mathrm{Zr})$ bearing a 3,4-dimethylcyclopentadienyl ring: Investigation of the substitution effect on the cyclopentadienyl (Cp) ring for catalytic performance in ethylene/1-octene (co)polymerization. Polyhedron 2014, 67, 199-204.

22. Hong, M.; Cui, L.; Liu, S.; Li, Y. Synthesis of novel cyclic olefin copolymer (COC) with high performance via effective copolymerization of ethylene with bulky cyclic olefin. Macromolecules 2012, 45, 5397-5402. [CrossRef]

23. Cho, D.J.; Wu, C.J.; Sujith, S.; Han, W.S.; Kang, S.O.; Lee, B.Y. o-Phenylene-bridged Cp/amido titanium complexes for ethylene/1-hexene copolymerizations. Organometallics 2006, 25, 2133-2134. [CrossRef]

24. Lee, S.H.; Wu, C.J.; Joung, U.G.; Lee, B.Y.; Park, J. Bimetallic phenylene-bridged Cp/amide titanium complexes and their olefin polymerization. Dalton Trans. 2007, 4608-4614. [CrossRef] [PubMed]

25. Wu, C.J.; Lee, S.H.; Yun, H.; Lee, B.Y. Ortho lithiation of tetrahydroquinoline derivatives and its use for the facile construction of polymerization catalysts. Organometallics 2007, 26, 6685-6687. [CrossRef]

26. Wu, C.J.; Lee, S.H.; Yu, S.T.; Na, S.J.; Yun, H.; Lee, B.Y. $\mathrm{CO}_{2}$-Mediated ortho-lithiation of N-alkylanilines and its use for the construction of polymerization catalysts. Organometallics 2008, 27, 3907-3917. [CrossRef]

27. Park, J.H.; Do, S.H.; Cyriac, A.; Yun, H.; Lee, B.Y. Preparation of half-metallocenes of thiophene-fused and tetrahydroquinoline-linked cyclopentadienyl ligands for ethylene/ $\alpha$-olefin copolymerization. Dalton Trans. 2010, 39, 9994-10002. [CrossRef] [PubMed]

28. Yu, S.T.; Na, S.J.; Lim, T.S.; Lee, B.Y. Preparation of a bulky cycloolefin/ethylene copolymer and its tensile properties. Macromolecules 2010, 43, 725-730. [CrossRef] 
29. Lee, C.H.; Lee, E.J.; Jung, S.W.; Lee, J.A.; Lee, B.R.; Lee, B.Y. Method for Preparing Transition Metal Complexes, Transition Metal Complexes Prepared Using the Method, Catalyst Composition Containing the Complexes. U.S. Patent 7932207B2, 26 April 2011.

30. Tremblay, J.-F. Dow chemical loses elastomers patent lawsuit against LG Chem. Chem. Eng. News 2012, 90, 7.

31. Lin, F.; Wang, X.; Pan, Y.; Wang, M.; Liu, B.; Luo, Y.; Cui, D. Nature of the entire range of rare earth metal-based cationic catalysts for highly active and syndioselective styrene polymerization. ACS Catal. 2016, 6, 176-185. [CrossRef]

32. Ryabov, A.N.; Voskoboynikov, A.Z. Constrained geometry complexes of titanium (IV) and zirconium (IV) involving cyclopentadienyl fused to thiophene ring. J. Organomet. Chem. 2005, 690, 4213-4221. [CrossRef]

33. Cai, Z.; Ohmagari, M.; Nakayama, Y.; Shiono, T. Highly active syndiospecific living polymerization of higher 1-alkene with ansa-fluorenylamidodimethyltitanium complex. Macromol. Rapid Commun. 2009, 30, 1812-1816. [CrossRef] [PubMed]

34. Schwerdtfeger, E.D.; Irwin, L.J.; Miller, S.A. Highly branched polyethylene from ethylene alone via a single zirconium-based catalyst. Macromolecules 2008, 41, 1080-1085. [CrossRef]

35. Ramos, C.; Royo, P.; Lanfranchi, M.; Pellinghelli, M.A.; Tiripicchio, A. [(Allylsilyl)( $\eta$-amidosilyl)- $\eta^{5}$ cyclopentadienyl] Group 4 Metal Complexes: Synthesis, Reactivity, and Olefin Polymerization. Organometallics 2007, 26, 445-454. [CrossRef]

36. Klosin, J.; Kruper, W.J.; Nickias, P.N.; Roof, G.R.; De Waele, P.; Abboud, K.A. Heteroatom-substituted constrained-geometry complexes. Dramatic substituent effect on catalyst efficiency and polymer molecular weight. Organometallics 2001, 20, 2663-2665. [CrossRef]

37. Van Leusen, D.; Beetstra, D.J.; Hessen, B.; Teuben, J.H. Ethylene-bridged tetramethylcyclopentadienylamide titanium complexes: Ligand synthesis and olefin polymerization properties. Organometallics 2000, 19, 4084-4089. [CrossRef]

38. Altenhoff, G.; Bredeau, S.; Erker, G.; Kehr, G.; Kataeva, O.; Fröhlich, R. Structural features of Me 2 Si-bridged $\mathrm{Cp} /$ phosphido group 4 metal complexes, "CpSiP" constrained-geometry Ziegler-Natta catalyst precursors. Organometallics 2002, 21, 4084-4089. [CrossRef]

39. Dureen, M.A.; Brown, C.C.; Morton, J.G.M.; Stephan, D.W. Titanium "constrained geometry" complexes with pendant arene groups. Dalton Trans. 2011, 40, 2861-2867. [CrossRef] [PubMed]

40. Piola, L.; Nahra, F.; Nolan, S.P. Olefin metathesis in air. Beil. J. Org. Chem. 2015, 11, 2038-2056. [CrossRef] [PubMed]

41. Schrock, R.R.; Murdzek, J.S.; Bazan, G.C.; Robbins, J.; DiMare, M.; O’Regan, M. Synthesis of molybdenum imido alkylidene complexes and some reactions involving acyclic olefins. J. Am. Chem. Soc. 1990, 112, 3875-3886. [CrossRef]

42. Wang, C.; Yu, M.; Kyle, A.F.; Jakubec, P.; Dixon, D.J.; Schrock, R.R.; Hoveyda, A.H. Efficient and selective formation of macrocyclic disubstituted $\mathrm{Z}$ alkenes by ring-closing metathesis (RCM) reactions catalyzed by Mo- or W-based monoaryloxide pyrrolide (MAP) complexes: Applications to total syntheses of epilachnene, yuzu lactone, ambrettolide, epothilone C, and nakadomarin A. Chem. Eur. J. 2013, 19, 2726-2740. [PubMed]

43. Ogasawara, M.; Arae, S.; Watanabe, S.; Nakajima, K.; Takahashi, T. Kinetic resolution of planar-chiral ferrocenylphosphine derivatives by molybdenum-catalyzed asymmetric ring-closing metathesis and their application in asymmetric catalysis. ACS Catal. 2016, 6, 1308-1315. [CrossRef]

44. Ogasawara, M.; Arae, S.; Watanabe, S.; Nakajima, K.; Takahashi, T. Kinetic resolution of planar-chiral 1,2-disubstituted ferrocenes by molybdenum-catalyzed asymmetric intraannular ring-closing metathesis. Chem. Eur. J. 2013, 19, 4151-4154. [CrossRef] [PubMed]

45. Grandini, C.; Camurati, I.; Guidotti, S.; Mascellani, N.; Resconi, L.; Nifant'ev, I.E.; Kashulin, I.A.; Ivchenko, P.V.; Mercandelli, P.; Sironi, A. Heterocycle-fused indenyl silyl amido dimethyl titanium complexes as catalysts for high molecular weight syndiotactic amorphous polypropylene. Organometallics 2004, 23, 344-360. [CrossRef]

46. Kim, S.; Park, J.; Song, B.; Yoon, S.-W.; Go, M.; Lee, J.; Lee, B. Preparation of thiophene-fused and tetrahydroquinoline-linked cyclopentadienyl titanium complexes for ethylene/ $\alpha$-olefin copolymerization. Catalysts 2013, 3, 104-124. [CrossRef]

47. Wang, W.-J.; Kolodka, E.; Zhu, S.; Hamielec, A.E.; Kostanski, L.K. Temperature rising elution fractionation and characterization of ethylene/octene-1 copolymers synthesized with constrained geometry catalyst. Macromol. Chem. Phys. 1999, 200, 2146-2151. [CrossRef] 
48. Theurkauff, G.; Bondon, A.; Dorcet, V.; Carpentier, J.-F.; Kirillov, E. Heterobi- and -trimetallic Ion Pairs of Zirconocene-Based Isoselective Olefin Polymerization Catalysts with AlMe 3 . Angew. Chem. Int. Ed. 2015, 54, 6343-6346. [CrossRef] [PubMed]

49. Song, F.; Cannon, R.D.; Bochmann, M. Zirconocene-catalyzed propene polymerization: A quenched-flow kinetic study. J. Am. Chem. Soc. 2003, 125, 7641-7653. [CrossRef] [PubMed]

50. Shreve, A.P.; Mulhaupt, R.; Fultz, W.; Calabrese, J.; Robbins, W.; Ittel, S.D. Sterically hindered aryloxidesubstituted alkylaluminum compounds. Organometallics 1988, 7, 409-416. [CrossRef]

51. Busico, V.; Cipullo, R.; Cutillo, F.; Friederichs, N.; Ronca, S.; Wang, B. Improving the performance of methylalumoxane: A facile and efficient method to trap "free" trimethylaluminum. J. Am. Chem. Soc. 2003, 125, 12402-12403. [CrossRef] [PubMed]

52. Mehdiabadi, S.; Soares, J.B.P.; Bilbao, D.; Brinen, J. Ethylene polymerization and ethylene/1-octene copolymerization with rac-dimethylsilylbis(indenyl)hafnium dimethyl using trioctyl aluminum and borate: A polymerization kinetics investigation. Macromolecules 2013, 46, 1312-1324. [CrossRef]

53. Wang, Q.; Li, L.; Fan, Z. Effects of tetraalkylaluminoxane activators on ethylene polymerization catalyzed by iron-based complexes. Eur. Polym. J. 2005, 41, 1170-1176. [CrossRef]

54. Wang, Q.; Li, L.; Fan, Z. Effect of alkylaluminum on ethylene polymerization catalyzed by 2,6-bis(imino)pyridyl complexes of Fe(II). J. Polym. Sci. Part A Polym. Chem. 2005, 43, 1599-1606. [CrossRef]

55. Dong, J.J.; Harvey, E.C.; Fañanás-Mastral, M.; Browne, W.R.; Feringa, B.L. Palladium-catalyzed anti-markovnikov oxidation of allylic amides to protected $\beta$-amino aldehydes. J. Am. Chem. Soc. 2014, 136, 17302-17307. [CrossRef] [PubMed]

56. Fletcher, A.J.; Bax, M.N.; Willis, M.C. Palladium-catalysed N-annulation routes to indoles: The synthesis of indoles with sterically demanding $N$-substituents, including demethylasterriquinone A1. Chem. Commun. 2007, 45, 4764-4766. [CrossRef] [PubMed]

Sample Availability: Sample of the compound $\mathbf{1 4}$ is available from the authors.

(C) 2017 by the authors; licensee MDPI, Basel, Switzerland. This article is an open access article distributed under the terms and conditions of the Creative Commons Attribution (CC BY) license (http:/ / creativecommons.org/licenses/by/4.0/). 